Chapter 4

\title{
Mycobacterium avium Complex in Domestic and Wild Animals
}

\author{
Ana Cláudia Coelho, Maria de Lurdes Pinto, \\ Ana Matos, Manuela Matos and \\ Maria dos Anjos Pires \\ Additional information is available at the end of the chapter \\ http://dx.doi.org/10.5772/54323
}

\section{Introduction}

Mycobacteria from the Mycobacterium avium complex (MAC) cause a variety of diseases including tuberculosis-like disease in humans and birds, disseminated infections in AIDS patients and otherwise immunocompromised patients, lymphadenitis in humans and mammals and paratuberculosis in ruminants. M. avium subsp. paratuberculosis (Map) is the etiologic agent of Johne's disease in cattle and it has been identified in human patients with Crohn's disease. The MAC comprises slow growing mycobacteria that are ubiquitous in the environment (soil and water), and have a wide source range, causing disease in various domestic and wild mammals and birds [1].

The aim of this study was to discuss the classification and biology, epidemiology, clinical signs, pathology, diagnostic techniques, and public health concerns in Mycobacterium avium complex in domestic and wild animals.

\section{Classification and biology of Mycobacterium avium complex}

The phylum Actinobacteria is large and very complex; it contains one class (Actinobacteria), five subclasses, six orders, 14 suborders, and 40 families. The orders, suborders, and families are defined based on $16 \mathrm{~S}$ rRNA sequences and distinctive signature nucleotides. The suborder Corynebacterineae contains seven families with several well-known genera. Three of the most important genera are Corynebacterium, Mycobacterium, and Nocardia [2]. 
The species of Mycobacterium, sole genus of the family Mycobacteriaceae, is composed of a group of high genomic $C+G$ content ( $\sim 61$ to $71 \%$ ), facultative intracellular, Gram-positive microorganisms comprising more than 130 established and validated species and subspecies [3], with surprisingly diverse phenotypes related to growth rate, metabolic activity, colony appearance, environmental distribution, and pathogenic potential for eukaryotic hosts [4]. Although most of these species are saprophytic, important human and animal pathogens have been identified. Pathogenic members are usually characterized by their slow growth in culture, with generation times of 12 to $24 \mathrm{~h}$, and must be incubated for 2 to 40 days after inoculation of a solidified complex medium to form a visible colony, whereas nonpathogenic members grow considerably faster [5]. Mycobacteria are acid-fast bacilli, acidophilic, small, slightly curved or straight rods that sometimes branch or form filaments. Mycobacterial filaments differ from those of actinomycetes in readily fragmenting into rods and coccoid bodies when distributed. They are aerobic, immobile, non-sporulated and catalase positive bacteria. Their cell wall is lipid-rich and contain waxes with 60 to 90 carbon mycolic acids, which are complex fatty acids with a hydroxyl group on the $\beta$-carbon and an aliphatic chain attached to the $\alpha$-carbon. The presence of mycolic acids and other lipids, in high concentration outside the peptidoglycan, makes mycobacteria acid-fast dye resistant (basic fuchsin cannot be removed from the cell by acid alcohol treatment), as well as resistant to immune system defense mechanisms and disinfectants $[2,6]$.

\subsection{Mycobacterium avium complex (MAC)}

Bacteria from the Mycobacterium avium complex (MAC) differ in virulence and ecology, and are the most frequently isolated non-tuberculous mycobacteria [7]. Mycobacterium members of MAC have the capacity to survive and multiply under a wide range of environmental conditions, including low $\mathrm{pH}$, extreme temperatures, chlorine or ozone treatment and low oxygen level. Thus, plus their ability to utilize many substances as nutrients, enables them to grow successfully in many biotopes [1]. The environmental sources responsible for MAC infection in different populations, the specific routes of infection and transmission, the potential for latent infection and reactivation of disease are not yet well defined [4,8]. Ingestion of environmental organisms followed by invasion through the gastrointestinal tract has been suggested as the main route of infection because the organisms are frequently isolated from stools of different animals. There is also an important positive correlation between the presence of MAC in respiratory samples and the subsequent development of disseminated disease [9]. Traditionally, MAC includes two species, Mycobacterium avium and Mycobacterium intracellulare [3]. Recently, advances in molecular taxonomy have fuelled identification of novel species within the MAC, including the Mycobacterium chimaera incorporating sequevar MAC-A organisms isolated from humans with pulmonary cavitations, pulmonary abscess, chronic obstructive pulmonary disease and bronchiectasis [10]; the Mycobacterium colombiense incorporating sequevar MAC-X organisms isolated from the blood and sputum of HIV infected patients in Colombia [11], and from diseased lymph nodes in children [12,13]; the Mycobacterium arosiense, recently described in an immunocompromised child with disseminated osteomyelitic lesions [14]; the Mycobacterium vulneris [15], Mycobacterium marseillense, Mycobacterium timonense and Mycobacterium bouchedurhonense isolated from patients 
with pulmonary disease. On the basis of genotypic, phenotypic and growth characteristics, biochemical tests and historical reasons, multiple subspecies of Mycobacterium avium are recognized. These include the subsp. avium, subsp. paratuberculosis, subsp. hominissuis and subsp. silvaticum [3]. All four Mycobacterium avium subspecies and Mycobacterium intracellulare are capable of infecting a diverse range of host and possess a high degree of genetic similarity [17]. Contemporary methods for MAC identification, e.g., high performance liquid chromatography (HPLC) of cell wall mycolic acids and genetic probes based on rRNA targets, e.g. AccuProbe, cannot discriminate among Mycobacterium avium subspecies. Given the differences in pathogenicity among Mycobacterium avium subspecies and the implications regarding the infection source, a practical and accurate method of simply identifying Mycobacterium avium subspecies is needed [18].

\subsection{Mycobacterium avium subsp. avium}

Before establishing the Mycobacterium avium subsp. avium (Maa) designation, this bacterium was simply referred to as Mycobacterium avium and has long been recognized as a primary pathogen causing avian tuberculosis in wild and domestic birds as well as in a variety of fowl, game birds and water-fowl. The most common route of infection for susceptible animals is the alimentary tract. Respiratory tract is also suggested as a potential source of infection [19].

\subsection{Mycobacterium avium subsp. paratuberculosis}

Mycobacterium avium subsp. paratuberculosis (Map) is the etiologic agent of Johne's disease or paratuberculosis, a chronic granulomatous enteritis of ruminant livestock and wildlife, with worldwide distribution having a significant impact on the world economy [5]. For veterinary medicine, Map is the MAC member of greatest importance, and is capable of infecting and causing disease in a wide array of animal species, including nonhuman primates, without the need for co-existent immunosuppressive infections [18]. Map is one of the slowest growing mycobacterial species, hence primary isolation from specimen, requires prolonged culture incubation and can take several months. Unlike most other Mycobacterium avium subspecies, isolation of Map requires the addition of the siderophore mycobactin to culture media [20]. From phenotypic analysis, the Map group has been subdivided into two main types, bovine and ovine, that vary in hosts, diseases caused, and growth phenotypes [21]. Genotypically, these findings were based primarily on comparisons of the integration loci of the IS900 insertion sequence (IS) and used polymorphisms in IS1311 to separate sheep and cattle isolates into separate populations [22].

\subsection{Mycobacterium avium subsp. hominissuis}

MAC isolates of genotypes IS901- and IS1245+ and serotypes 4 to 6, 8 to 11 and 21 are less virulent for birds and are designated M. avium subsp. hominissuis (Mah). Mah was proposed to distinguish organisms found in humans and pigs from those isolated from birds [3]. Those are genomically diverse, the more diverse group of strains, low-virulence, opportunistic pathogens for both animals and humans [18]. Considered ubiquitous in the environment (the most likely source of infection for humans), Mah can cause serious systemic 
infection in immunocompromised patients, such as those infected with HIV. Additionally, this opportunistic pathogen can cause cervical lymphadenitis in children with cystic fibrosis, and lung infections in patients with underlying lung disease [23]. Domestic water distribution systems have been reported as possible sources of Mah infections in hospitals, family houses, and commercial places [24]. In animals, Mah is found as a cause of lymphadenitis of the head and mesenteric lymph nodes of swine documented at slaughter [18], and can also lead to systemic infection of parenchymatous organs [23]. Mah were recovered from affected lymph nodes of red deer from Austria [25].

\subsection{Mycobacterium avium subsp. silvaticum}

Mycobacterium avium subsp. silvaticum applies to the previously named wood pigeon bacillus, an acid-fast organism causing tuberculosis-like lesions in these wood pigeons. The inability to grow on egg media, the stimulation of growth by pyruvate and at $\mathrm{pH} 5.5$ and their mycobactin dependency upon primary isolation, gradually losing this phenotype upon subculture, have been described as characteristics of Mycobacterium avium subsp. silvaticum [17].

\subsection{Mycobacterium intracellulare}

Mycobacterium intracellulare, initially named Nocardia intracellularis, is an environmental organism and opportunistic pathogen, isolated from a variety of animal hosts and environmental sources. Mycobacterium intracellulare is a closely related pathogen of birds with a lower prevalence [26]. In general, it has been subject to less study than Mycobacterium avium, as the latter is more prevalent in clinical and environmental samples, has a wider apparent host range, and contributes almost exclusively to disseminated MAC disease in human immunodeficiency virus patients [3]. The type strain of Mycobacterium intracellulare (ATCC 13950) was isolated from a human, specifically responsible for enlarged lymph nodes in children, who died from disseminated disease [3], and progressive pulmonary disease in elderly women [27]. Mycobacterium intracellulare appears to have a distinct ecological niche, more prevalent in biofilms and at significantly higher CFU numbers than Mycobacterium avium [28].

\section{Clinical signs and morphology in domestic and wild species}

All ruminant species, captive or free-ranging, are susceptible to disease and death due to MAC infection [29], and a wide diversity of non-ruminant species can become infected with mycobateria belonging to MAC, especially with Map and Maa. Paratuberculosis has been described in cattle, small ruminants, deer, and in South American camelids (llamas and alpacas) $[30,31]$. This chronic disease is one of the most serious affecting dairy cattle worldwide showing symptoms of an insidious intestinal pathology responsible for significant economic losses [5]. The close relationship between wild, captive and domestic ruminants and other species like birds is, nowadays, clinically relevant as the wild population could act as reservoir for this agent [32]. 
In cattle this disease is scored in four stages according to its evolution and symptoms, two of them evolving sub-clinically. Stage I, or silent infection, is the most observed in young animals, without significant clinical signs and only in post mortem evaluation it is possible to identify the agent by culture or histopathology analysis [33].

Stage II remains a subclinical disease, being observed in adult animals. It may be detected by alterations in immunological serological and/or cellular parameters. Intermittently, fecal culture and histopathology analysis of these animals could be positive to Map [33].

In stage III the clinical signs can be observed, occurring after several years of incubation. The initial clinical signs are subtle with gradual weight loss despite normal appetite, intermittent diarrhea along several weeks, drop in milk production and roughness of hair coat. These symptoms are included in the differential diagnosis of multiple diseases, so it is often misdiagnosed [34]. Usually, animals in this stage are positive upon ELISA and other serological tests, as for histopathological analysis of lesions, which are common in the terminal ileum [35] (Figure 2A).

The last stage of the disease (stage IV) comprises animals that rapidly progress from the stage III with rapid condition deteriorated. They became increasingly lethargic, weak and emaciated and present intermandibular edema due to hypoproteinemia. In this stage, the culture of the agent, molecular biology techniques of PCR, ELISA, serology and histopathology (Figure 1), all are positive for the majority of animals tested. The gastrointestinal tract is the preferential local to sample in order to isolate the agent, but in some conditions it can even be present in extraintestinal lesions, with the liver and lymph nodes being the most common sites [33].
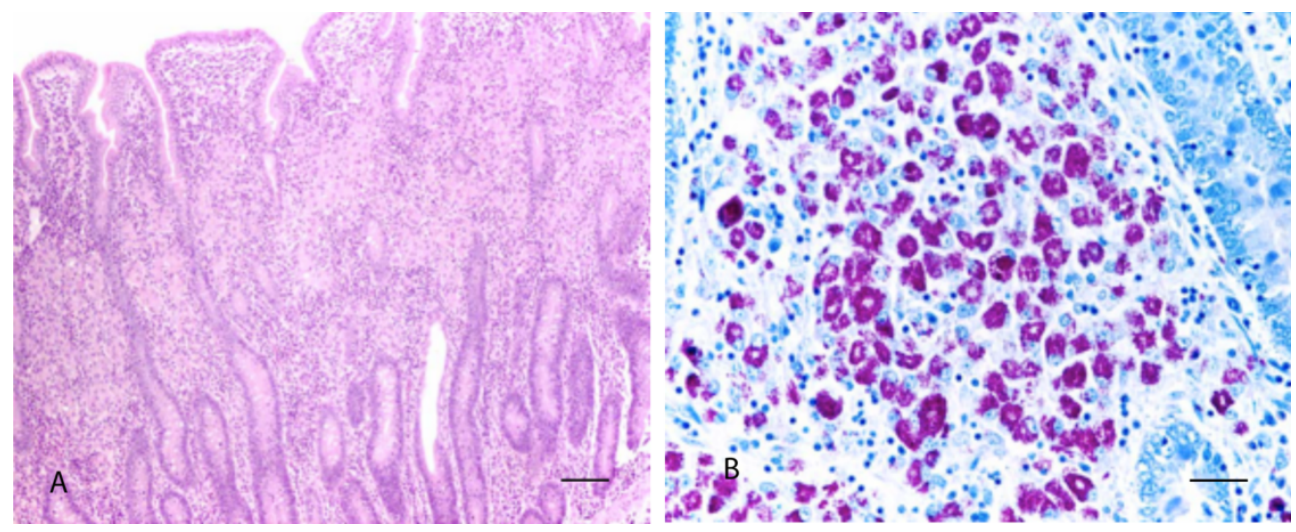

Figure 1. Morphological aspects of paratuberculosis lesions in the ileum of sheep. A- Thickening of the mucosa by an inflammatory infiltrate composed by epithelioid cells, macrophages and some multinucleated giant cells. (H\&E stain, Bar=50 $\mathrm{m}$ ) B- Acid-acohol resistant bacilli within the macrophages and epithelioid cells that infiltrate the mucosa. Notice the abundant number of mycobacteria that are visible at moderate amplification (Ziehl-Neelsen, Bar=30 $\mu \mathrm{m}$ ) 


\subsection{Clinical signs and lesions in wild species}

Mycobacteria belonging to the MAC can affect a wide-range of wild animals, but little has been published on the clinical signs, which are rarely perceived or not documented. When present, the occurrence of clinical signs and lesions is highly variable in timing but often similar to those of their domesticated counterparts. The vast majority of reports on MAC species affecting wildlife mention the Map and the Maa as the mycobacteria most commonly isolated in these animals.

\subsubsection{Wild ruminants}

The lesions observed in wild species of sheep and goats are identical to those of their domestic counterparts, while in the South American camelids the lesional pattern is similar to that of cattle. However in llamas and alpacas, in contrast to what is generally described in cattle, lymph node necrosis and mineralization, along with multiorganic dissemination, have also been reported [30,31]. As in the previously mentioned species, the most significant MAC species capable of causing clinical disease in free-living, captive and farmed deer are Map and Maa. Although Mah has been also isolated from lesions in deer [25,26] and Mycobacterium intracellulare was also found in deer species but they are not so common and it's infection is usually subclinical. Despite the occurrence of paratuberculosis in adults, outbreaks of the disease frequently occur in young deer of 8-15 months of age, contrary to the clinical disease in sheep and cattle which usually affects adults of 3-5 years of age [36]. Clinical signs of paratuberculosis in deer are similar to those described in sheep and cattle, with diarrhea and loss of weight and body condition [37]. Accordingly, the intestinal lesions of paratuberculosis in deer primarily affect the jejunum and ileum, and are identical to the typical lesions observed in sheep and goats [30]; yet, necrosis and mineralization in lymph nodes draining the gastrointestinal tract, especially those draining the ileum and ileocecal valve, are a common feature (Figure 2B). The lymph nodes are often enlarged, and a range of changes from yellow watery areas to caseous necrosis is observed on cut surfaces. The histologic changes in these lesions are very similar to those caused by Mycobacterium bovis and other members of the MAC genus [38,39]. Balseiro et al., have proposed an histopathological classification of lesions observed in natural occurring cases of paratuberculosis in free-ranging fallow deer (Dama dama), according to which the lesions would be graded into four categories: focal, multifocal, diffuse multibacillary, and diffuse intermediate (multibacillary-lymphocytic) lesions. Focal lesions are composed of small granulomas, mainly in the jejunal and ileal lymph nodes, whereas multifocal lesions consist in well-demarcated granulomas in the intestinal lymphoid tissue and also in the intestinal lamina propria. Diffuse multibacillary lesions are characterized by a severe granulomatous enteritis and lymphadenitis. Macrophages and numerous Langhan's multinucleatd giant cells (L-MGC) containing many mycobacteria are present, resulting in macroscopic changes in the normal gut morphology. These changes are found from the proximal jejunum to the ileocaecal valve, but lesions are always particularly severe in the distal jejunum. In the diffuse intermediate (multibacillary-lymphocytic) lesions, there is a prominence of lymphocytes, macrophages and L-MGC, with small numbers of mycobacteria [40]. In deer with clinical signs of paratuberculosis, disseminated granuloma- 
tous lesions in the lung and liver can also be observed [38]. A recent report in free-ranging red deer (Cervus elaphus) supports the possibility of multiorganic dissemination of Map in deer, since the agent was isolated from kidneys with granulomatous lesions [41].

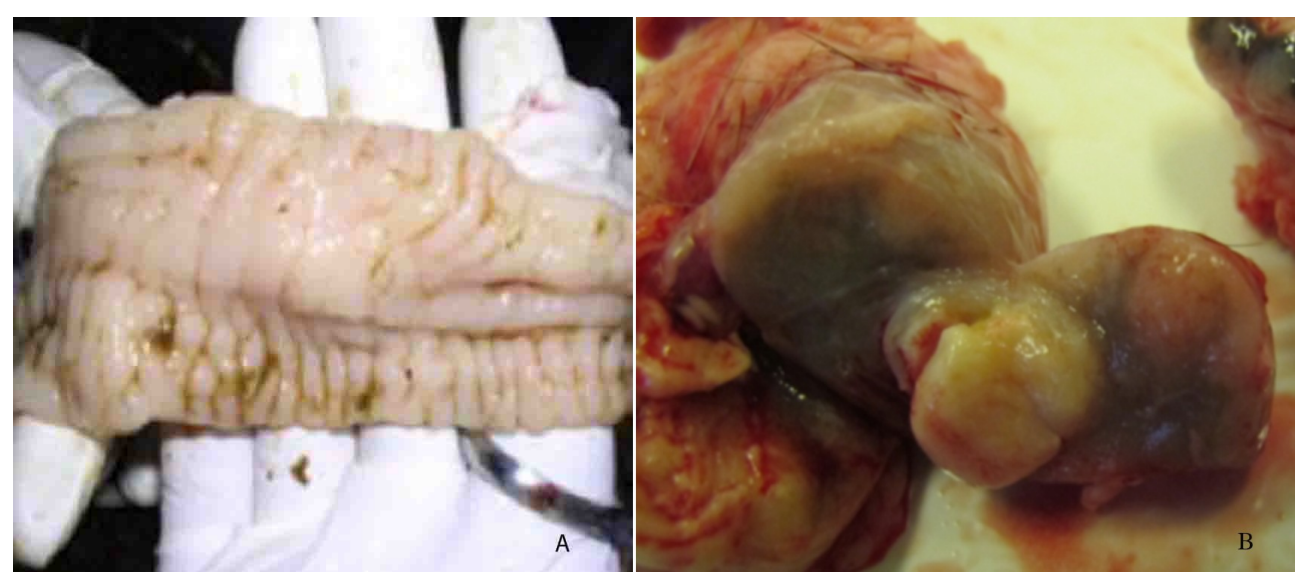

Figure 2. A - Paratuberculosis gross lesions in the ileum of sheep. Notice the increased thickness of the mucosa, with the characteristic folds and gyros B - Paratuberculosis lesions in the submandibularis lymph nodes of red deer (Cervus elaphus) with caseous necrosis.
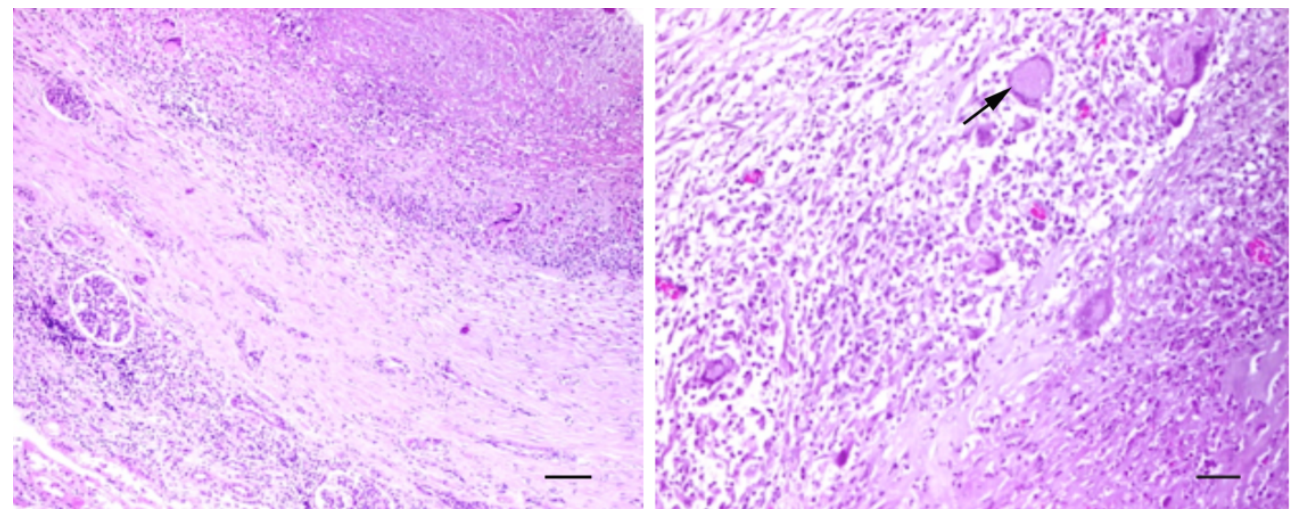

Figure 3. A - Morphological aspects of paratuberculosis lesions in the kidneys of deer (Cervus elaphus). A single granu-

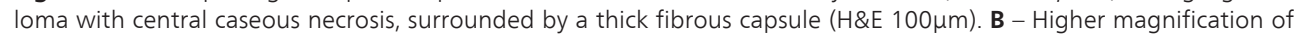

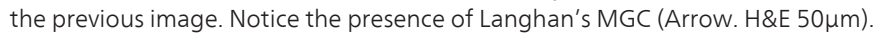

In deer, the infection by Maa is self-limiting as in other mammalian species [36,42]. The lesions may be purulent, caseous, or granulomatous [26], and are mainly present in the retropharyngeal lymph nodes and lymph nodes draining the intestinal tract (mesenteric and ileocaecal), consistent with the feco-oral route of infection. The granulomatous le- 
sions are grossly and histologically identical to the lesions caused by Mycobacterium bovis [42]. Mah lesions in deer are similar to those observed in animals with Maa infection, and although rare, both mycobacteria can cause systemic disease [26] with hematogenous spread to the liver and lungs to produce miliary lesions and a terminal septicemia [43]. Despite of these findings, Map and Maa infections can be present in apparently asymptomatic deer herds $[44,45]$. Furthermore, a study of wild Tule elks (Cervus elaphus nannodes) from California revealed no significant associations between MAC infection and microscopic lesions, such as presence of macrophages and/or multinucleate giant cells (MGC) in tissue sections [45] (Figure 3).

\subsubsection{Non-ruminant species}

Map has been isolated in a wide range of wild mammals, from rodents, badgers, racoons, nine-banded armadillos, opossums, northern short-tailed shrew, striped skunks [46-48], wild boars [32,49] and rhinoceros [50] to bears [51], but not all of them present the same susceptibility and develop clinical signs or lesions when infected. The lesions produced by Map, representative or not of paratuberculosis, as well as the clinical signs seen in non-ruminant wild animals are more subtle than those observed in wild-ruminant species. Monkeys (Macaca arctoides and Papio sphinx) have demonstrated susceptibility to Map infection and develop lesions that are confined to the intestine and abdominal lymph nodes, resembling the lesions of paratuberculosis in cattle and in humans Crohn's disease [52,53]. When infected by Map lagomorphs produce an intestinal disease similar to paratuberculosis in ruminants, and severe infection can occur naturally, in which extensive granulomas with numerous giants' cells carrying multiple acid-fast bacilli can be observed in the small intestine [54]. In foxes and stoats, Map affects the intestines and mesenteric lymph nodes with microscopic changes similar to those described in ruminants with subclinical paratuberculosis. The lesions are composed of single macrophagelike cells or discrete granulomas consisting of small numbers of macrophages, in the cortex and paracortex of the mesenteric lymph nodes. In the small intestine, only few numbers of intracellular acid-fast bacteria are present within the macrophages, and Langhan's-type MGC, irregularly scattered in the granulomas, in all layers of affected intestine $[46,54,55]$. The typical pathology of paratuberculosis has also been noted in wood mice, weasels, badgers [46], and rats infected with the predominant ruminant strains [56]. When present, in brushtail possum and hedgehogs infected with Map, the lesions observed are in the grastrointestinal tract [57]. A recent report revealed that wild Eurasian otters (Lutra lutra L.) could be infected with Map. In that study, no gross lesions were found, but the retropharyngeal and mesenteric lymph nodes presented disrupted architecture, lymphoid depletion and diffuse inflammatory infiltrate composed mainly of macrophages and, to a lesser extent, neutrophils. Map was identified by direct PCR in several organs, including the intestine and lymph nodes [58]. Reports in which Map was isolated from Eurasian wild boars (Sus scrofa) revealed that the infection can occur with or without lesions, the later being the most frequent. If present, lesions generally consist of granulomatous enteritis and mesenteric lymphadenitis [32,49]. In mesenteric lymph nodes, lymphadenitis with multifocal lesions ranging from less than $1 \mathrm{~cm}$ to large areas 
of more than $1 \mathrm{~cm}$ in diameter, of either necrotic or necrotic calcified granulomas are observed (Figure 4). The presence of lymphocytes and caseous necrosis are the most common findings in these lesions [59].
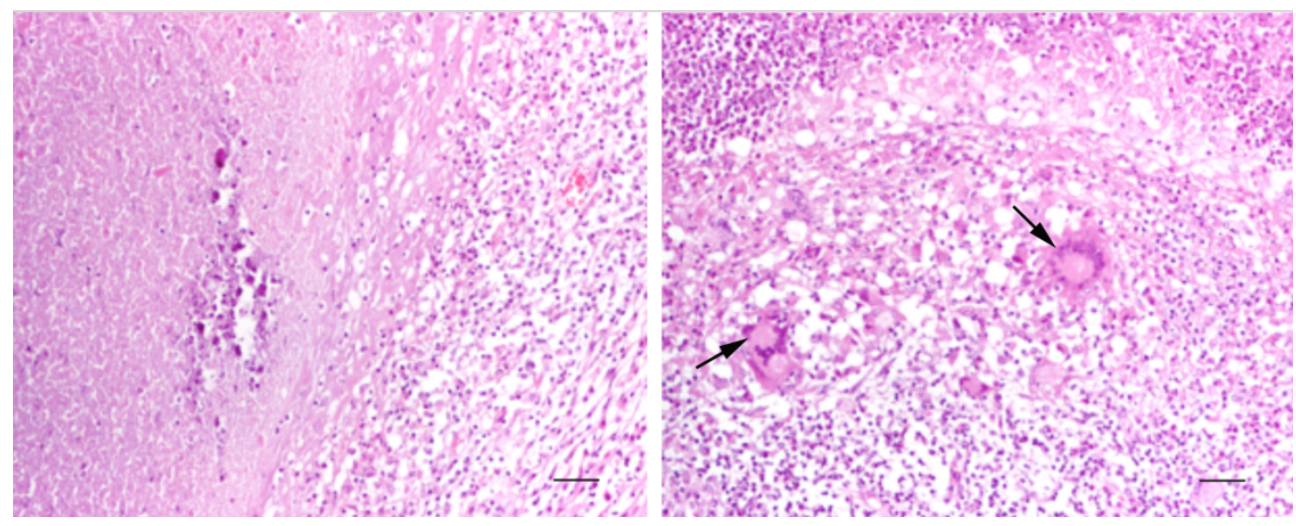

Figure 4. Morphological aspects of paratuberculosis lesions in wild boar (Sus scrofa). Presence of of multiple granulomas in the mesenteric lymph nodes (H\&E 50 $\mathrm{m}$ ). A - Notice the caseous necrosis surrounded by inflammatory cells predominantly macrophages and some fibroblasts. B - Higher magnification of the former image. Note the Langhan's MGC (Arrows. H\&E 50um).

Despite Maa being widely reported in wild boar, data on clinical infection or mortality are scarce [49]. Apparently, natural infection with this mycobateria causes barely detectable clinical signs or lesions [49]. However, there are reports of Maa isolated from free-ranging Eurasian wild boars with tuberculous lesions in intestinal lymph nodes [60], and the experimental infection with high doses of Maa results in gross and histopathological lesions of tuberculosis in tracheobronchial and mandibular lymph nodes. All visible lesions are less than $10 \mathrm{~mm}$ in diameter and consist of typical tuberculous granulomas with a central caseous necrosis, variably mineralized, surrounded by macrophages, lymphocytes, neutrophils, eosinophils and occasional MGC surrounded by fibrous tissue. Acid-fast bacilli are rarely detected in the necrotic debris of these lesions [61]. Another study also showed that in wild boars with mesenteric and submaxillar lymphadenitis, Mycobacterium avium subspecies type 1 and M. avium subspecies type 2 were the most frequently isolated mycobacteria [62].

Regarding Mah in wild boar, recent reports suggest that this animal species may act as a reservoir for these mycobacteria, since it was detected in lymph nodes without gross lesions or microscopic lesions $[60,63]$.

\subsection{Bird species}

Bird species, either domestic or free-living can be infected with MAC mycobacteria, but they are more susceptible to Maa, the causative agent of avian tuberculosis [19]. Infection by $M$. avium subsp. paratuberculosis has been also documented in birds, with and without clinical and pathological findings [46,57]. 
Maa belonging to serotypes 1, 2, 3, and 6 is the most common agent of avian tuberculosis, but other species belonging to MAC, such as M. intracellulare, are also sporadic causes of disease [19]. Tuberculosis affects a wide-range of bird species, and it has been documented in waterfowl, galliformes, columbiformes, passerines, psittacines, raptors, and ratites [64-67]. According to their susceptibility to the disease, it has been proposed the classification of bird species into four groups, from highly susceptible to highly resistant: (1) domestic fowl, sparrows, pheasants, and partridges; (2) guinea fowl and domestic turkeys; (3) domestic goose and duck; (4) domestic pigeon [19]. The clinical signs of avian tuberculosis are well established but are not pathognomonic, and are different according to the phase of infection and the predominant form of the disease in the bird species, which in turn is related to the species susceptibility to the agent. Avian tuberculosis usually presents three stages or phases: latency, lesion development, and period of cachexia [68,69]. In most reports on the initial phase of avian tuberculosis the absence of clinical signs is a common feature. On the contrary, in advanced cases, progressive weight loss, depression, white diarrhea with soiled feathers, increased thirst, respiratory distress, fatigue, and decreased egg production may be observed [68]. Generally, avian tuberculosis is an intestinal and hepatic disease that can disseminate to other organs including the lungs, air sacs, spleen, bone marrow, and skin [69]. This is considered as the classical form of infection, and it's marked by the presence of tubercles or granulomas in multiple organs. Lesions in the intestinal tract characterize a second form of infection, and a third type of infection, especially reported finches, canaries, and psittacines occurs without the development of tuberculous lesions $[19,68,69]$. The clinical signs of the intestinal form of tuberculosis are characterized by chronic wasting disease. In severe cases and as disease progresses, feathers are often dull or ruffled and comb, wattle, and earlobes are paler, thinner and dry. Birds become lethargic and emaciated with marked atrophy of breast muscles, displaying the typical "knife edged" keel. In extreme cases, the body fat disappears, and the bird's face looks smaller than normal. The body temperature of the affected birds remains normal, even in severe cases $[68,69]$. Sudden death may also occur, as well as dyspnea, granulomatous ocular lesions [70] and skin lesions, which are less frequent $[68,69]$. Sudden death may be the result of massive hemorrhage secondary to liver or spleen rupture. In such cases, the birds may exhibit good body condition but frequently show advanced lesions of tuberculosis. Lameness can be the result of bone dissemination, in particular to the bone marrow of long bones. Joints can also be affected, and as consequence, some birds may adapt a sitting position or even show paralysis. There are also reports of neurological signs, due to the involvement of vertebral or central nervous system [68]. The lesions of avian tuberculosis are mainly composed by epithelioid cells containing large numbers of bacterium, that may either diffusely infiltrate the organ or form discrete tubercles or granulomas [68]. In the classical and intestinal forms of the disease, studded greyish-white to greyish-yellow nodules are frequently observed. The nodules, which appear as tumourlike masses, bulge from the serosal surface of the intestine and can be palpable. These nodules may suffer ulceration, and the caseous material within may be discharge into the intestinal lumen leading to the excretion of mycobacteria in droppings. During dissemination, typical caseous lesions, without calcification, are always found in the liver and spleen, with considerable enlargement of the organs. Nodules are firm but can be incised easily 
since mineralization is rare in avian tuberculosis. Due to this, spleen takes irregular and "knobbly" appearance. With the disease progression, tubercular nodules in the bone marrow, ovaries and testes, are often seen. Pulmonary lesions, which are a striking feature of tuberculosis in other species, are rarely observed in birds $[68,69]$. Pulmonary avian tuberculosis is not common, but it has been reported occasionally in pigeons and water-fowl $[19,65,69]$. In the cachexia stage of avian tuberculosis, massive tubercles with large numbers of bacilli are observed [68,69].

In accordance to the clinical signs and lesional patterns of tuberculosis in domestic species, captive, exotic and wild birds, including raptors, generally develop the disseminated form of avian tuberculosis, involving the digestive tract, liver and spleen [66,71,72]. However, some studies reveal that exotic bird species may have lesions in the liver and spleen without intestinal involvement. These lesions are typical granulomas with a caseous or coagulative necrotic centre and MGC. Acid-fast bacilli are numerous in the central zone of the tubercle [69].

Infection of birds by Map has been reported, but it often occurs without clinical signs or lesions, despite the typical lesions of paratuberculosis being described in jackdaws (Corvus monedula), rooks (Corvus frugilegus), and crows (Corvus corone) [46,57]. A study also reported the occurrence of diarrhea, respiratory signs, hepatomegaly and splenomegaly in a diamond sparrow (Emblema guttata) with liver granuloma lesions, predominantly composed of lymphocytes and mononuclear cells [73].

\section{Diagnostic techniques}

The diagnosis of Mac is based on the clinical signs, post mortem gross lesions, and by demonstrating the presence of acid-fast bacilli using Ziehl-Neelsen staining. This is normally sufficient to establish the diagnosis $[68,69,74,75]$. Ante mortem diagnosis is based on clinical signs, leukograme, serology, culture and also acid-fast stain or biopsy samples of fluids or organs [76-80]. Radiography and ultrasonography are also useful in the medical evaluation of birds [79].

\subsection{Isolation and identification}

The golden standard test for mycobacterium diagnosis is the microbiological culture. Tissue culture seems to be slightly more sensitive than faecal culture and it allows the infection to be detected in some animals that had no specific lesions. The culture of bacteria requires weeks or months of incubation before colony growth occurs. This means that a significant amount of time is needed before a diagnosis can be made. It is also difficult to isolate bacteria in culture due to intermittent shedding and a low number of bacilli in faeces and tissues [81]. M. genavense is extremely difficult to isolate by culture [82,83]. M. avium complex grows best in media containing eggs or egg yolk and the incubation temperature should be set at $37^{\circ} \mathrm{C}-40^{\circ} \mathrm{C}$. Culture can be performed in Dorset's, Herrold's egg yolk medium, Middlebrook 7H10 and 7H11 or Coletsos medium supplemented with 1\% sodium piruvate [68,74,75]. For 
the isolation of Map or M. silvaticum addition of mycobactin is required in all media. Map is the slowest growing of the culturable mycobacteria [84]. Cultures should be incubated for at least 8 weeks. Typically, M. avium produces smooth colonies within 2-4 weeks and rough variants can occur [74]. Culture of Map from faeces or tissues of other animals such as sheep and goats is less successful due to the "S" strains that usually infect these animals [84]. The best organs to use for culture are usually liver and spleen but bone marrow can be used if carcass is decomposed, as it could be less contaminated [74]. Non-sterile specimens need to be processed with detergent alkali or acid to eliminate rapidly growing microorganisms before culture decontamination in order to remove faster growing microbial species. Incubation with various decontamination agents such as $0.6-0.75 \%$ hexadecylpryridinium chloride (HPC) or $\mathrm{NaOH}$ for 3 hours to overnight, have been used. It is important that decontamination does not remove too many viable mycobacterium cells $[85,86]$. Other methods like sedimentation and centrifugation can be employed if small numbers of mycobacteria are expected in the sample [85,87]. Shorter incubation times can be achieved using automated broth based systems, like liquid culture BACTEC system MGIT 960 [84]. These systems have been reported to be highly sensitive for culture [88]. For M. genavense the use of BACTEC system with no additives and $\mathrm{pH} 6.0$ is recommended $[89,90]$. Middlebrook 7H11 with pH 6.0 supplemented with blood and charcoal is also recommended to promote growth of $M$. genavense [91]. In human AIDS patients, laboratory diagnosis of MAC infection is usually made by the BACTEC blood culture [92]. Conventional biochemical tests for species identification are lengthy and fail to distinguish between M. avium and M. intracelullare [74]. Identification of isolates by phenotypic characteristics of majority of clinically relevant mycobacteria can be based on growth rates, colony pigmentation and biochemical tests such as niacin production, nitrate reduction, tween 80 hydrolysis arylsulphatase, urease, tellurite reduction, thiophen-2-carboxylic acid hydrazide sensitivity catalase (qualitative and quantitative) growth on MacConkey and sodium chloride tolerance [88,93].

Classification of MAC organisms has been made by seroagglutination [19,74]. Seroagglutination is based on sugar residue specificity of surface glycopeptidolipids, and allows classification of MAC organisms into 28 serovars: 1 to 6,8 to 11 and 21 are currently ascribed as M. avium, while serovars 7,12 to 20 and 25 to $M$. intracellulare. However, no consensus was achieved on the other serovars [74]. MAC colonies can also be identified using high performance liquid chromatography (HPLC) for detecting mycolic acid [19]. HPLC and the use of monoclonal antibodies to major serovars in ELISA also facilitate typing of mycobacteria $[19,75]$.

\subsection{Immunological methods}

The enzyme linked immunosorbent assay (ELISA) has been used for detecting antimycobacterial antibodies in the serum of ruminants [94]. However, serological assays for detecting Mycobacterium are problematic. The sensitivity of ELISA is dependent on the stage of the disease with a higher sensitivity of the test in case of higher bacterial load. The test can detect the most severe infections in multibacillar lesions but shows lower sensitivity in animals with paucibacillar lesions [84]. One important disadvantage is the inability to distinguish be- 
tween different mycobacterial infections probably due to close antigenic relationship between Maa and Map [95].

Tuberculin test is the most widely used method in domestic fowl and the only for which an international standard for the reagent exists. Birds are tested by intradermal inoculation in the wattle with $0.05 \mathrm{ml}$ or $0.1 \mathrm{ml}$ of tuberculin (avian purified protein derivate PPD) [74]. A positive reaction is identified as a hot and oedematous swelling at the site or by the presence of a small firm nodule of approximately $5 \mathrm{~mm}$ in diameter after 48 hours [19]. The tuberculin test and the haemagglutination test (stained antigen) are the immunological methods most frequently used for export testing [74]. In the stained antigen test an antigen stained with $1 \%$ malachite green is used for the rapid blood plate agglutination test [96].The diagnosis of Mycobacterial infections in live wild animals remains a challenge [95]. The comparative cervical tuberculin (CCT) skin test has been applied in wild animals such as in cervids [97], but the test presents two major limitations. It has been proved that CCT cannot detect some stages of infection [98], and wild ruminants must be captured twice increasing the stress and the risk of accidents for the animals and for handlers [95]. Alternative probes like the detection of interferon- $\gamma$ (IFN- $\gamma$ ) assay and ELISA, which employ blood and serum respectively, could be an alternative in wild animals [95]. Advantages of ELISA and IFN- $\gamma$ assay is that they enable testing without handling the animals twice and allow repeated testing, which are important advantages in case of wild ruminants [99]. ELISA detects humoral immune response whereas the CCT and IFN- $\gamma$ assay detect cellular immune response [95]. The dominant response to mycobacterial infections in ruminants is cell-mediated. However, a recent study demonstrated that the IFN- $\gamma$ assay may be of limited usefulness in some species of cervids [100].

\subsection{Genetic methods}

\subsubsection{The contribution of molecular biology to MAC research}

During the past several years, many molecular methods have been developed for direct detection, species identification, and drug susceptibility testing of mycobacteria. These methods can potentially reduce the diagnostic time from weeks to days with a higher sensibility. Molecular biology methods offer new opportunities to differentiate, identify and type bacterial species and strains. These methods use the variability of nucleic sequences of genes such as $16 \mathrm{~S}$ rDNA, beta subunit RNA-ase (rpoB), gyrase (gyrB), rDNA internal transcribed spacer among other genes. Some of the methods available to differentiate and identify species of mycobacteria at the DNA sequence level are PCR, PCR-REA, sequencing analysis, spoligotyping and DNA fingerprinting. These methods have been applied to both the "universal" part of the genome and to specific mycobacterial genes.

Isolation of mycobacterial DNA can be done from living mycobacteria, not only from mycobacterial isolates but also directly from body fluids (sputum, bronchoalveolar lavages, and bronchial and tracheal aspirates, semen, milk, blood, cerebrospinal fluid), from tissues and from faeces and can be done using dead mycobacterial cells, namely from formalin-fixed 
and paraffin-embedded tissues and from forensic and archaeological samples [101]. One of the challenges with molecular detection of Map is to get the genomic DNA out of the bacteria, which is protected by its thick and waxy cell wall. One method commonly used is the mechanical disruption by the use of bead beating, a general term for using small beads mixed with the sample, usually in the presence of a proteolytic enzyme and lysis buffer, to break tissues or tough cell walls and spores by forceful shaking in a cell disrupter, or "bead beater". It is one of several suggested methods to lyse Map [102-105]. Others include homogenized (grinded) sample under liquid nitrogen in a mortar and pestle, combinations of enzymatic treatment, freeze-thaw/boiling and kits for plant DNA purification or for animal tissues DNA purification [103,105-109]. Commercially available kits, developed for DNA isolation from different matrices, are commonly used for the rapid isolation and detection of Map in milk.

\subsubsection{Polymerase Chain Reaction (PCR)}

The polymerase chain reaction (PCR) is an in vitro method for the amplification of DNA that was introduced in 1985 [110]. With the performance of a previous reverse transcription step, PCR can also be applied to RNA [111]. Reverse transcription PCR is a modification of this method used when the initial template is RNA rather than DNA, the reverse transcriptase enzyme first converts the RNA target into a complementary DNA copy (cDNA), that can be used to amplify the much higher numbers of copies of messenger or ribosomal RNA than the number of DNA copies present in bacteria, and it may detect specific expression of certain genes. Some modifications to single PCR were done to improve results and were used for MAC species detection, the multiplex PCR, the assay that include several primer pairs specific to different DNA targets to allow amplification and detection of several pathogens at the same time, and nested PCR, the product from one PCR reaction serves as template in a second reaction with fresh reagents, thus diluting any PCR inhibiting substances and increasing the sensitivity. As example differentiation of $M$. tuberculosis complex, M. avium and other non-tuberculous mycobacteria (NTM) has been done by using hybridization probes [112]. Targeting the 16S rRNA gene, 3 different probes, specific for mycobacteria, M. tuberculosis complex and $M$. avium, were constructed and the thermal melting temperature (Tm) was different for M. tuberculosis, M. kansasii, M. avium, M. intracellulare and M. marinum allowing the differentiation. TaqMan PCR assay targeting $65 \mathrm{kD}$ heat shock protein gene has been used for the detection of M. genavense and M. avium complex species in avian tissue samples [83].

Specific probes are available for the identification of Mycobacterium avium and Mycobacterium intracellulare. Amplification of the DT1 and DT6 fragments was considered equally sensitive for species identification [113]. Recently, numerous isolates suspected of be $M y$ cobacterium intracellulare were reclassified as Mycobacterium chimaera sp. nov., as part of the MAC [114]. Strains of MAC can be identified by serological procedures, on the basis of differences in the C-mycoside glycopeptidolipids. To date, using $16 \mathrm{~S}$ rRNA probes, 28 MAC serotypes have been identified from which the serotypes 1-6, 8-11, and 21 belong 
to Maa. Serovars 7, 12-20, and 25 have been ascribed to Mycobacterium intracellulare. Serovar- 1 is the most common organism isolated from birds and from human. Serotypes 1 and 2 are most commonly isolated from domestic birds, and serovar 3 is recovered sporadically from wild birds. Serotypes 1,2 , and 3 are considered virulent for chickens. Serotypes 1, 4, and 8 have been reported to predominate among isolates from AIDS patients [19].

Other approach to the differentiation of MAC strains was obtained with the description of repetitive insertion sequence IS900 in Map strains and IS901 or IS902 in M. avium subsp. silvaticum strains [115]. Examination of serotyped strains revealed IS901 only in strains of serotypes 1, 2, and 3 [19].

The discovery of insertion sequences in mycobacterial genomes, e.g. IS900 in Map [116], IS901 [117], IS1245 [118], IS1311 [119] in the MAC strains was a major breakthrough in the study of mycobacterial infections. When characterized and used in the proper context, the species-specific IS (insertion sequences) elements can be useful classification tools to distinguish subsets of the MAC $[18,120]$. However, there are two problems described that can question their utility for this purpose. First, a number of IS elements have been uncovered in strains considered to be MAC organisms, but without adequate strain characterization, it is difficult to judge which organisms harbour such elements. Second, IS elements are by nature mobile elements, so there is a risk that similar elements are found in unrelated bacteria because of mobility to or from MAC organisms [3].

IS900 was the first IS characterized within the Mycobacterium genus [116,121] and is the most widely used target sequence for detection of Map and presently considered specific for this agent. The Map genome is reported to have 15 to 20 copies of the insertion element, and the sequenced strain K-10 has 17 copies [122]. Cousins et al. recommended that restriction digestion should be used to confirm the profile of the IS of the amplified product [123]. However, Englund et al. identified a Mycobacterium sp. with an IS900 like sequence in which the restriction sites after amplification with the original primers were identical to the restriction sites in amplified DNA of Map [124]. Therefore, restriction endonucleases analysis did not solve the problem of false positives. Englund et al. recommended that a positive IS900 PCR should be confirmed by subsequent sequencing or by a PCR assay targeting another gene in Map [124]. In a study performed by Vansnick et al. two sets of newly developed PCR primers based on the insertion sequence IS900 and the unique sequence f57 were developed and the combination of the two PCR assays has proven to be useful for the identification of Map [125]. Map genome has revealed the presence of 17 IS900, 7 IS1311, and 3 IS1245 insertion elements. The IS900 element seems unique to Map and has been widely used as a diagnostic tool to detect Map in clinical samples from both animals and humans [5].

The specific DNA sequence IS900 was also used as the target for Map detection in Nested PCR. In 2002, IS900-nested PCR was used to determine the specificity and sensitivity of a commercial ELISA test [126]. However, the nested PCR method is now being replaced by Real-Time PCR [127]. 
RFLP analysis of the IS900 element has been used a molecular tool to type Map isolates and allowed the division of Map into different groups, associated to different host species [3]. The IS900 element is by far the most widely used target for the molecular detection of Map and has been used in the form of direct PCR [108,125], in situ PCR [128] nested PCR $[126,129,130]$, and real-time PCR [131-133]. Sequencing of the amplified product for IS900 is therefore necessary to confirm that the amplicon is truly IS900.

Additional gene loci specific for Map have been identified and suggested for use in diagnostics: ISMav2 [134], f57 [135], ISMap02 [136], and other Map specific coding sequences [137].

To identify the methods which are best suited for diagnostics, eight single-round and five nested PCR systems including twelve different primer pairs based on IS900 (9x), 7 ISMav2 (1x), f57 (1x), and locus 255 (1x) sequences were compared by Möbius et al., which concluded that stringent selection of IS900-specific primers ensures that IS900 remains a favourite target sequence for amplification of Map specific loci [138]. A PCR system targeting two different Map specific regions would have a still higher specificity. The following six single round PCR-systems were recommended by Möbius et al. [138]: IS900 based PCRs of Englund et al. [139], and Doran et al. [140], the f57 based PCR assay [125], and the locus 255 based PCR assay [137]. However, despite their advantages, such as a hundredfold enhancement of sensitivity, nested PCR assays bear a high risk of contamination and crossing over and, therefore, cannot be recommended as a reliable method for routine diagnosis of Map.

The insertion sequence IS901 was discovered by Kunze et al. and shows around 60\% sequence homology to IS900 [117]. The stability of IS901 in strains isolated primarily from clinical material from birds, domestic animals and from the environment is used for the rapid identification of IS901+ strains using the PCR method. Screening across a larger panel of isolates revealed that most isolates from birds and some animals contained the element, whereas isolates obtained from AIDS patients or the environment did not. Furthermore, it was found that most bird isolates had similar IS901 patterns [3].

IS1311 was first reported as a GenBank entry in 1994 (U16276) and was subsequently used for RFLP analyses $[119,141]$. This element is present in all members of the M. avium subspecies, including Maa, Mah, and Map [142], and is not present in M. intracellulare [22,141]. The element itself has $85 \%$ sequence identity to IS1245. With the wide range of M. avium hosting for this element, it is possible that IS1311 represents an "older" IS element which may have been present prior to subspecies divergence [3]. RFLP analysis of IS1311 and the use of IS1311 PCR-REA also revealed distinct pattern types, corresponding to different genotype species strains of M. avium subsp. paratuberculosis [22,142].

The IS1245 was first described in 1995, is present in up to 27 copies in Mycobacterium avium [118], was presented as having a more restricted range than IS1311, and was found to be stable during in vivo and in vitro passage, making it a popular target for restriction fragment length polymorphism strain typing. It is described as limited to the subspecies of M. avium, i.e., Maa (that would include Mah), Map subsp. paratuberculosis, and M. avium subsp. silvaticum. By PCR analysis, this element was not found in M. intracellulare or in 17 other mycobacterium species [3]. Standardization of IS1245 RFLP analysis was proposed in 1998 as a tool 
for MAC molecular epidemiology [143]. Some M. avium isolates have been documented as being IS1245 negative, but only a few such reports have presented further documentation of strain identity by a sequence-based method [144]. Beggs et al. found IS1245 in strains of $M$. intracellulare, demonstrating that the element is present in other species of the M. avium complex [144]. In some reports, IS1245-negative isolates have been described that contain an hsp65 sequence identical to that of M. avium but that differs from M. avium in other taxonomic targets, such as the 16S rRNA gene and the ITS sequence [3].

Other identification methods of $M$. avium species or its subspecies are based on $16 \mathrm{~S}$ rDNA [145], PCR-REA (Restriction Endonuclease Analysis) [146], sequence analysis of hsp65 [8] or a strategy based on large sequence polymorphisms [147]. Semret et al. evaluating the distribution of genomic polymorphisms across a panel of strains, verified that it was possible to assign unique genomic signatures to host-associated variants and based on these polymorphisms proposed a simple PCR-based strategy that can rapidly type M. avium isolates into these subgroups [147].

The sequence of the $16 \mathrm{~S}$ rDNA gene is specific at the species level and is also a stable property of microorganisms. Wilton and Cousins described a method for the simultaneous identification of genus, species and strains of Mycobacterium sp. using conserved and variable sequences of the 16S rDNA gene [145]. Comparing the 16S rDNA sequences of mycobacterial pathogens, they found variable regions specific for individual species and used the information to develop a duplex amplification system, which makes it possible to identify the genus Mycobacterium, and the species M. a. avium and M. intracellulare. If combining the primers for $16 \mathrm{~S}$ rDNA with primers specific to the gene that encodes the secretion protein MPB70 (specific for Mycobacterium tuberculosis complex) this system permits the detection and identification of clinically important mycobacteria in one single PCR. The disadvantage of this method is that it does not distinguish between M. a. avium and M. a. paratuberculosis.

Combining PCR amplification of the 16S rDNA gene and subsequent restriction analysis we have the PCR-REA (or PRA) method. Using the $16 \mathrm{~S}$ rDNA gene primers according to Thierry et al. and the resulting PCR products, $1300 \mathrm{bp}$ in size digested with Rsa I it is possible to distinguish species of MAC (M. a. avium serotypes 1-3, 8-11 and 21, M. a. paratuberculosis) and M. intracellulare (serotypes 7, 12-20, 22-28) [148].

Standard (housekeeping) genes offer a higher level of sequence variation than do ribosomal genes but are nonetheless useful for taxonomic purposes due to the relative sequence conservation imposed to maintain function. In this category, the stress protein gene hsp65 is a preferred target for mycobacterial identification to the species level, having been routinely used in diagnostics since the development of rapid PCR-restriction enzyme analysis (PRA) methods. The dnaJ gene encodes a stress chaperone protein and is highly conserved among the bacterial genera [149]. Morakova et al. designed primers specific for the dnaJ gene in the $M$. avium species that allow amplification of the dnaJ gene in all isolates of all M. avium subspecies and the authors suggest using them as an internal standard in the multiplex PCR to control inhibition of the amplification, and consequently false negatives, because are highly specific for at least M. avium [108]. The same team designed a fast and specific PCR strategy for the detection and differentiation of M. avium subspecies for use in routine veterinary di- 
agnosis [108]. They have developed a multiplex PCR based on IS900, IS901, IS1245 and the dnaJ gene. This method allows the detection of M. a. paratuberculosis, M. a. hominissuis and M. a. avium/M. a. silvaticum in one PCR reaction (PCR multiplex) and theoretically enables the detection of mixed infections of M. a. paratuberculosis and M. a. avium or M. a. paratuberculosis and M. a. hominissuis. The sensitivity of this multiplex PCR is 103 CFU for each bacterial strain in one PCR reaction, which also enabled the use of this test directly for DNA isolated from the tissue of the heavily infected sheep.

Shin et al. designed a five-target multiplex PCR to discriminate MAC organisms isolated. This MAC multiplex was designed to amplify a $16 \mathrm{~S}$ rRNA gene target common to all Mycobacterium species, a chromosomal target called DT1 that is unique to Maa serotypes 2 and 3, to $M$. avium subsp. silvaticum, and to M. intracellulare, and three insertion sequences, IS900, IS901, and IS1311. The results for the pattern of amplification allowed to determine whether isolates were mycobacteria, or members of MAC, and to classify them into one of the three major MAC subspecies, Map, Maa, Mah [18].

\section{Public health concerns}

Zoonotic aspects of mycobacteria transmitted by the environment and wildlife highlights a major health problem. MAC causes a variety of disorders including tuberculosis-like diseases in animals and in human immunocompetent or immunocompromised patients. Susceptibility to mycobacterial infections depends of risk factors since they are ubiquous in the soil and water [150]. Human exposure to mycobacterium present in wildlife and in nature can occur by a variety of routes. Humans are continuously exposed at a low level (50 to 5000 bacilli per day). Contact with water, municipal or natural are also important routes for mycobacteria infection. Birds are major excretors of the agent in their faeces and the bacteria can persist in the soil and in water for long [1].

Healthy humans have a low susceptibility to MAC infection and only a very small percentage of mycobacteria progress trough to infection, but in immunocompromised individuals infected with HIV or leukaemia patients, treated with steroid therapy, chemotherapy or other immunosuppressive medication, should be carefully considered regarding their possibility to come in contact with birds with mycobacterial infection [1,151]. Prior to the introduction of highly active antiretroviral treatment more than $40 \%$ of patients developed M. avium complex bacteriemia two years after the AIDS diagnosis [152] and a disseminated MAC infection was found in as much as $50 \%$ of autopsied AIDS patients $[153,154]$. This has predominantly been attributed to the impairment of the adaptative part of the immune systems in HIV-1 infected individuals due to the loss of CD4+ T cells, as the susceptibility to opportunistic infections including M. avium infection is correlated with a decline in this cell type [155]. MAC usually produces clinical disease only when CD4+ are very low ( $<50$ cells/ $\mathrm{ml}$ ), which is seen in 4 to 5 per cent of HIV infected patients [88]. A recent study showed that exposure of dendritic cells to HIV-1 promotes or facilitates the intracellular growth of $M$. avium [153]. Signs and symptoms associated with MAC disease in AIDS cases are persistent 
high grade fever, high sweats, anaemia and weight loss in addition to nonspecific symptoms of malaise, anorexia, diarrhea, myalgia and occasional painful adenophaty [88]. Epidemiology of MAC complex in patients without HIV infection remains somewhat difficult to determine since the disease is relatively uncommon, it is not a reportable health event and environmental exposure varies greatly according to the geographic region [156]. In an epidemiological survey in USA from 2000 to 2003 performed in [156] in patients without HIV infection the rate of positive non-tuberculous cultures was 17.7 per 100,000. Surveys conducted in Europe estimated the rate of disease anywhere in the human body to be 0.8-3.1 per 100,000 [157,158]. In a recent study, Bodle et al. estimated the incidence of non-tuberculous mycobacteria in the respiratory tract disease in 2.0 per 100,000 and the disease in anywhere in the human body in 2.7 per 100,000 [156]. Another recently published study showed that the patient's lung disease was likely acquired by inhalation of aerosols while showering [159]. M. avium may reach the lungs by aspiration because a considerable percentage of patients with non-tuberculous mycobacteria (NMT) disease have been found to experience gastroesophageal reflux disease [160,161].

Disease patterns of MAC are different in immunocompromised patients. In adults, infection is mainly pulmonary $[1,151]$. MAC is the most common of the nontuberculous mycobacteria found in apparently healthy children [162] and it's infection is characterized by a chronic granulomatous lymphadenopathy in the neck region that preferably is treated by excision of the affected lymph node [162,163]. The main hypothesis of infection is that oral contact with M. avium-infected water courses causes lymphadenitis in the head and neck region in children $[162,164]$. Among the members of MAC, Maa is predominant (87-98\%) in AIDS patients and induces disseminated mycobacteriemia rather than restrict the bacteria to the lungs [1]. Since the advent of AIDS, HIV has become the major risk factor for MAC infection. In AIDS patients the main route of infection is the gastrointestinal tract and M. avium is naturally tolerant to the low $\mathrm{pH}$ that exists in the stomach $[19,165]$. Regarding therapeutics, M. avium is of special concern because drugs commonly used from treating tuberculosis in humans are not effective [166] and MAC strains are resistant to isoniazid, the most popular anti-tuberculosis drug [19,167]. Preexisting pulmonary conditions, patients with current illness or immunosuppressive medication are the most important risk factors for MAC infection amongst patients without HIV infection. MAC was also reported as the most common pathogen causing post transplant non-tuberculous mycobacteria disease [156]. Other factors are local traumas and surgical procedures injuries [168]. Chronic obstructive pulmonary disease, emphysema, pneumoconiosis, aspiration due to oesophageal disease, previous gastrectomy and chronic alcoholism are some of the conditions which have been linked to disease $[88,154]$. Disseminated MAC infection is more frequent in caucasians compared with Hispanic or African-americans individuals. However, there are no differences related with age $[169,170]$. Infection is more frequent in men than in women, particularly in homosexual and bisexual men, when compared to other HIV risk categories.

The zoonotic potential of Map has been debated for almost a century because of similarities between Johne's disease in cattle and Crohn's disease in humans. A quarter century later since Map was first proposed as an etiologic agent in Crohn's disease based on the isolation 
of the organism from several patients the association as a causative agent or in an incidental away remains unresolved. Milk and water are potential sources for acquiring Map infection [171]. However, only a few samples of milk, positive by PCR for the presence of Map have yielded positive results in culture, suggesting that Map remains undetectable probably because the low number of viable Map in samples [172]. Published reports indicate that Map may not be completely inactivated by pasteurization of milk [173]. Serological response to Map in humans is also not conclusive [172]. Traditional methods of detecting bacteria, culture and stain are largely ineffective in detecting Map in humans. Bacteria are very difficult to culture and Map is able to exist in a spheroplast (cell wall deficient form) in humans so it cannot be identified by Ziehl-Neelsen staining [174-176]. Polymerase chain reaction has identified Map in greater than $90 \%$ of biopsy specimens from Crohn's patients [177] and viable Map was detected in peripheral blood and serum in a higher proportion of individuals with Crohn's disease $[178,179]$. However, culture of Map from human specimens is a controversial question since some authors pointed out the difficulty of culturing Map [180,181]. At this moment is not possible to know if Map is a primary etiological agent or secondary invader and further research is need to understand the possible links between this agent and Crohn disease [1].

There is a recent interest in Map as an immune trigger of several autoimmune diseases $[182,183]$. Environmental agents are postulated to trigger autism. Recently, a theory proposing a mechanism by which Map triggers autism through molecular mimicry to the heat shock protein HSP65, which stimulates antibodies that cross react with myelin basic protein, a common feature of autism [184]. Another recent study has associated the presence of Map with Blau syndrome, an autossomal dominant, and systemic inflammatory disease. The mutations of Blau syndrome are on the same gene on chromosome 16 (CARD 15) that confers susceptibility to Crohns'disease [185]. Map was also implicated in sarcoidosis [186,187], which is a multisystemic granulomatous disease with many features in common with mycobacterial infection, and that, like Crohn's disease, can be mimicked by slow bacterial infections $[188,189]$.

Map was also linked to ulcerative colitis, irritable bowel syndrome, autoimmune (type 1) diabetes, Hashimoto thyroiditis and multiple sclerosis $[179,184]$. Increasing evidence suggests a role for Map in autoimmune (type I) diabetes. It is postulated that this bacterium acts via molecular mimicry between its antigens (HSP65) and the pancreatic enzyme glutamic acid decarboxylase (GAD) [190-195].

\section{Conclusion}

MAC comprises slow growing mycobacteria that are ubiquitous in the environment (soil and water), and have a wide source range, causing disease in various domestic and wild mammals and birds. MAC can affect a wide-range of wild animals, but little has been published up to the moment on the clinical signs, which are rarely exhibited or not documented. When present, the occurrence of clinical signs and lesions is highly variable in timing, though often similar to those of their domesticated counterparts. 
The evidence for the zoonotic potential should not be neglected particularly in immunocompromised patients, both humans and animals.

Recent reports, suggesting an association between MAC and autoimmune and other chronic human diseases, alert to the importance of developing new studies on MAC biology, molecular diagnosis and epidemiology.

Research to understand the impact of MAC in public health is needed as well as the determination of transmission routes between humans and wildlife, which requires interdisciplinary collaboration among medical, veterinary and other public health officials.

\section{Acknowledgements}

The work was supported by the strategic research project PEst-OE/AGR/UI0772/2011 financed by the Foundation for Science and Technology (FCT).

\section{Author details}

Ana Cláudia Coelho ${ }^{1}$, Maria de Lurdes Pinto $^{1}$, Ana Matos ${ }^{2}$, Manuela Matos ${ }^{3}$ and Maria dos Anjos Pires ${ }^{1}$

1 CECAV- Animal and Veterinary Research Center, University of Trás-os-Montes and AltoDouro, Department of Veterinary Sciences, Vila Real, Portugal

2 School of Agriculture, Polytechnic Institute of Castelo Branco, Castelo Branco, Portugal

3 Department of Genetics and Biotechnology, IBB-Institute for Biotechnology and Bioengineering, Centre of Genomic and Biotechnology, University of Trás-os-Montes and AltoDouro, Vila Real, Portugal

\section{References}

[1] Biet F, Boschiroli ML, Thorel MF, Guilloteau LA. Zoonotic Aspects of Mycobacterium bovis and Mycobacterium avium-intracellulare Complex (MAC). Veterinary research. 2005;36(3) 411-436.

[2] Prescott LM, Harley JP, Klein DA. Microbiology. New York: McGraw-Hill; 2002.

[3] Turenne CY, Wallace R, Behr MA. Mycobacterium avium in the Postgenomic Era. Clinical Microbiology Reviews. 2007;20(2) 205-229.

[4] Smole SC, McAleese F, Ngampasutadol J, von Reyn CF, Arbeit RD. Clinical and Epidemiological Correlates of Genotypes within the Mycobacterium avium Complex 
Defined by Restriction and Sequence Analysis of hsp65. Journal of Clinical Microbiology. 2002;40(9) 3374-3380.

[5] Harris NB, Barletta RG. Mycobacterium avium subsp. paratuberculosis in Veterinary Medicine. Clinical Microbiology Reviews. 2001;14(3) 489-512.

[6] Carter G, Wise D. Mycobacterium. In: Carter G, Wise D (ed.) Essentials of Veterinary Bacteriology and Mycology. Iowa: Iowa State Pres; 2004. p. 207-213.

[7] Mackenzie N, Alexander DC, Turenne CY, Behr MA, De Buck JM. Genomic Comparison of PE and PPE Genes in the Mycobacterium avium Complex. Journal of Clinical Microbiology. 2009;47(4) 1002-1011.

[8] Turenne CY, Semret M, Cousins DV, Collins DM, Behr MA. Sequencing of hsp65 Distinguishes among Subsets of the Mycobacterium avium Complex. Journal of Clinical Microbiology. 2006;44(2) 433-440.

[9] Inderlied CB, Kemper CA, Bermudez LE. The Mycobacterium avium Complex. Clinical Microbiology Reviews. 1993;6(3) 266-310.

[10] Tortoli E, Rindi L, Garcia MJ, Chiaradonna P, Dei R, Garzelli C, Kroppenstedt RM, Lari N, Mattei R, Mariottini A, Mazzarelli G, Murcia MI, Nanetti A, Piccoli P, Scarparo C. Proposal to Elevate the Genetic Variant MAC-A, Included in the Mycobacterium avium complex, to species rank as Mycobacterium chimaera sp. nov. International Journal of Systematic and Evolutionary Microbiology. 2004;54(4) 1277-1285.

[11] Murcia MI, Tortoli E, Menendez MC, Palenque E, Garcia MJ. Mycobacterium colombiense sp. nov., a Novel Member of the Mycobacterium avium Complex and Description of MAC-X as a New ITS Genetic Variant. International Journal of Systematic and Evolutionary Microbiology. 2006;56(9) 2049-2054.

[12] Esparcia Á, Navarro F, Quer M, Coll P. Lymphadenopathy Caused by Mycobacterium colombiense. Journal of Clinical Microbiology. 2008;46(5) 1885-1887.

[13] Vuorenmaa K, Ben Salah I, Barlogis V, Chambost H, Drancourt M. Mycobacterium colombiense and Pseudotuberculous Lymphadenopathy.. Emerging Infectious Diseases. 2009;15(4) 619-620.

[14] Bang D, Herlin T, Stegger M, Andersen AB, Torkko P, Tortoli E, Thomsen VO. Mycobacterium arosiense sp. nov., a Slowly Growing, Scotochromogenic Species Causing Osteomyelitis in an Immunocompromised Child. International Journal of Systematic and Evolutionary Microbiology. 2008;58(10) 2398-2402.

[15] Van Ingen J, Boeree MJ, Kásters K, Wieland A, Tortoli E, Dekhuijzen PNR, van Soolingen D. Proposal to Elevate Mycobacterium avium Complex ITS Sequevar MAC-Q to Mycobacterium vulneris sp. nov. International Journal of Systematic and Evolutionary Microbiology. 2009;59(9) 2277-2282.

[16] Ben Salah I, Cayrou C, Raoult D, Drancourt M. Mycobacterium marseillense sp. nov., Mycobacterium timonense sp. nov. and Mycobacterium bouchedurhonense sp. nov., 
Members of the Mycobacterium Avium Complex. International Journal of Systematic and Evolutionary Microbiology. 2009;59(11) 2803-2808.

[17] Thorel M-F, Krichevsky M, Vincent Lévy-Frébault V. Numerical Taxonomy of Mycobactin-Dependent Mycobacteria, Emended Description of Mycobacterium avium, and Description of Mycobacterium avium subsp. avium subsp. nov., Mycobacterium avium subsp. paratuberculosis subsp. nov., and Mycobacterium avium subsp. silvaticum subsp. nov. International Journal of Systematic Bacteriology. 1990;40(3) 254-260.

[18] Shin SJ, Lee BS, Koh W-J, Manning EJB, Anklam K, Sreevatsan S, Lambrecht RS, Collins MT. Efficient Differentiation of Mycobacterium avium Complex Species and Subspecies by Use of Five-Target Multiplex PCR. Journal of Clinical Microbiology. 2010;48(11) 4057-4062.

[19] Dhama K, Mahendran M, Tiwari R, Dayal Singh S, Kumar D, Singh S, Sawant PM. Tuberculosis in Birds: Insights into the Mycobacterium avium Infections. Veterinary Medicine International. 2011; 2011:1-14. http://dx.doi.org/10.4061/2011/712369.

[20] Wells SJ, Collins MT, Faaberg KS, Wees C, Tavornpanich S, Petrini KR, Collins JE, Cernicchiaro N, Whitlock RH. Evaluation of a Rapid Fecal PCR Test for Detection of Mycobacterium avium subsp. paratuberculosis in Dairy Cattle. Clinical and Vaccine Immunology. 2006;13(10) 1125-1130.

[21] Whittington RJ, Marsh I, McAllister S, Turner MJ, Marshall DJ, Fraser CA. Evaluation of Modified BACTEC 12B Radiometric Medium and Solid Media for Culture of Mycobacterium avium subsp. paratuberculosis from Sheep. Journal of Clinical Microbiology. 1999;37(4) 1077-1083.

[22] Whittington R, I., Marsh EC, Cousins D. Polymorphisms In IS1311, an Insertion Sequence Common to Mycobacterium avium and M. avium subsp. paratuberculosis, Can Be Used to Distinguish Between and within these Species. Molecular and Cellular Probes. 1998;12(6) 349-358.

[23] Álvarez J, García IG, Aranaz A, Bezos J, Romero B, de Juan L, Mateos A, GómezMampaso E, Domínguez L. Genetic Diversity of Mycobacterium avium Isolates Recovered from Clinical Samples and from the Environment: Molecular Characterization for Diagnostic Purposes. Journal of Clinical Microbiology. 2008;46(4) 1246-1251.

[24] Matlova L, Dvorska L, Palecek K, Maurenc L, Bartos M, Pavlik I. Impact of Sawdust and Wood Shavings in Bedding on Pig Tuberculous Lesions in Lymph nodes, and IS1245 RFLP Analysis of Mycobacterium avium subsp. hominissuis of Serotypes 6 and 8 isolated from pigs and environment. Veterinary Microbiology. 2004;102(3-4) 227-236.

[25] Glawischnig W, Steineck T, Spergser J. Infections Caused by Mycobacterium avium subspecies avium, Hominissuis, and paratuberculosis in Free-Ranging Red Deer (Cervus elaphus hippelaphus) in Austria, 2001-2004. Journal of Wildlife Diseases. 2006;42(4) 724-731. 
[26] Thorel MF, Huchzermeyer HF, Michel AL. Mycobacterium avium and Mycobacterium intracellulare Infection in Mammals. Revue scientifique et technique (International Office of Epizootics). 2001;20(1) 204-218.

[27] Kyriakopoulos AM, Tassios PT, Matsiota-Bernard P, Marinis E, Tsaousidou S, Legakis NJ. Characterization to Species Level of Mycobacterium avium Complex Strains from Human Immunodeficiency Virus-Positive and -Negative Patients. Journal of Clinical Microbiology. 1997;35(11) 3001-3003.

[28] Falkinham JO, Norton CD, LeChevallier MW. Factors Influencing Numbers of Mycobacterium avium, Mycobacterium intracellulare, and other Mycobacteria in Drinking Water Distribution Systems. Applied and Environmental Microbiology. 2001;67(3) 1225-1231.

[29] Manning EJ. Paratuberculosis in Captive and Free-Ranging Wildlife. The Veterinary clinics of North America. Food animal practice. 2011;27(3) 621-630.

[30] Stehman S. Paratuberculosis in Small Ruminants, Deer, and South American Camelids. Veterinary Clinics of North America-Food Animal Practice. 1996;12(2) 441-455.

[31] Committee on Diagnosis and Control of Johne's Disease NRC. Diagnosis and Control of Johne's Disease. Washington The National Academies Press; 2003. Available from: http://www.nap.edu/openbook.php?record_id=10625.

[32] Álvarez J, de Juan L, Briones V, Romero B, Aranaz A, Fernández-Garayzábal JF, Mateos A. Mycobacterium avium subspecies paratuberculosis in fallow deer and wild boar in Spain. Veterinary Record. 2005;156(7) 212-213.

[33] Rideout A, Brown S, Davis W, Gay J, Giannella R, Hines II M, Hueston W, Hutchinson L. Diagnosis and Control of Johne's Disease. Washington: The National Academies Press Washington; 2003.

[34] Whittington RJ, Sergeant ESG. Progress Towards Understanding the Spread, Detection and Control of Mycobacterium avium subsp para-tuberculosis in Animal Populations. Australian Veterinary Journal. 2001;79(4) 267-278.

[35] Coelho A. Estudo Epidemiológico da Paratuberculose Ovina na Região de Trás-osMontes e Alto Douro. Vila Real: University of Trás-os-Montes and Alto Douro; 2006.

[36] Mackintosh C, de Lisle G, Collins D, Griffin J. Mycobacterial Diseases of Deer. New Zealand Veterinary Journal. 2004;52(4) 163-174.

[37] Reyes-Garcia R, Pérez-de-la-Lastra JM, Vicente J, Ruiz-Fons F, Garrido JM, Gortázar C. Large-Scale ELISA Testing of Spanish Red Deer for Paratuberculosis. Veterinary Immunology and Immunopathology. 2008;124(1-2) 75-81.

[38] de Lisle GW, Yates GF, Collins DM. Paratuberculosis in Farmed Deer: Case Reports and DNA Characterization of Isolates of Mycobacterium paratuberculosis. Journal of Veterinary Diagnostic Investigation. 1993;5(4) 567-571. 
[39] de Lisle G, Yates GF, Montgomery H. The Emergence of Mycobacterium paratuberculosis in Farmed Deer in New Zealand - a Review of 619 Cases. New Zealand Veterinary Journal. 2003;51(2) 58-62.

[40] Balseiro A, García Marín JF, Solano P, Garrido JM, Prieto JM. Histopathological Classification of Lesions Observed in Natural Cases of Paratuberculosis in Free-ranging Fallow Deer (Dama dama). Journal of Comparative Pathology. 2008;138(4) 180-188.

[41] Matos A, Figueira L, Martins M, Matos M, Andrade S, Alvares S, Mendes A, Sousa N, Coelho A, Pinto M, editors. Renal Lesions in Deer (Cervus elaphus) - Mycobacterium avium subsp. paratuberculosis Involvelment. 30th Meeting of the European Society of Veterinary Pathology; 2012 September 5th to 8th Léon,Spain.

[42] de Lisle G, Joyce MA, Yates GF, Wards BJ, Hoyle FP. Mycobacterium avium Infection in a Farmed Deer Herd. New Zealand Veterinary Journal. 1995;43(1) 1-3.

[43] Griffin J. The aetiology of tuberculosis and mycobacterial diseases in farmed deer. Irish Veterinary Journal. 1988;42(1) 23-26.

[44] Machackova-Kopecna M, Bartos M, Straka M, Ludvik V, Svastova P, Alvarez J, Lamka J, Trcka I, Treml F, Parmova I, Pavlik I. Paratuberculosis and avian tuberculosis infections in one red deer farm studied by IS900 and IS901 RFLP analysis. Veterinary Microbiology. 2005;105(3-4) 261-268.

[45] Crawford GC, Ziccardi MH, Gonzales BJ, Woods LM, Fischer JK, Manning EJB, Mazet JAK. Mycobacterium avium subspecies paratuberculosis and Mycobacterium avium subsp. avium Infections in a Tule Elk (Cervus elaphus nannodes) Herd. Journal of Wildlife Diseases. 2006;42(4) 715-723.

[46] Beard PM, Daniels MJ, Henderson D, Pirie A, Rudge K, Buxton D, Rhind S, Greig A, Hutchings MR, McKendrick I, Stevenson K, Sharp JM. Paratuberculosis Infection of Nonruminant Wildlife in Scotland. Journal of Clinical Microbiology. 2001;39(4) 1517-1521.

[47] Corn JL, Manning EJB, Sreevatsan S, Fischer JR. Isolation of Mycobacterium avium subsp. paratuberculosis from Free-Ranging Birds and Mammals on Livestock Premises. Applied and Environmental Microbiology. 2005;71(11) 6963-6967.

[48] Deutz A, Spergser J, Wagner P, Rosengarten R, Köfer J. Mycobacterium avium subsp. paratuberculosis in wild animal species and cattle in Styria/Austria. Berliner und Munchener Tierarztliche Wochenschrift. 2005;118(7-8) 314-320.

[49] Machackova M, Matlova L, Lamka J, Smolik J, Melicharek I, Hanzlikova M, Docekal J, Cvetnic Z, Nagy G, Lipiec M, Ocepec M, Pavlik I. Wild boar (Sus scrofa) as a Possible Vector of Mycobacterial Infections: Review of Literature and Critical Analysis of Data from Central Europe Between 1983 to 2001. Veterinarni Medicina. 2003;48(3) 51-65 
[50] Cousins DV, Williams SN, Hope A, Eamens GJ. DNA Fingerprinting of Australian Isolates of Mycobacterium avium subsp paratuberculosis using IS900 RFLP. Australian Veterinary Journal. 2000;78(3) 184-190.

[51] Kopecna M, Ondrus S, Literak I, Klimes J, Horvathova A, Moravkova M, Bartos M, Trcka I, Pavlik I. Detection of Mycobacterium avium subsp. paratuberculosis in Two Brown Bears in the Central European Carpathians. Journal of Wildlife Diseases. 2006;42(3) 691-695.

[52] McClure HM, Chiodini RJ, Anderson DC, Swenson RB, Thayer WR, Coutu JA. Mycobacterium paratuberculosis Infection in a Colony of Stumptail Macaques (Macaca arctoides). Journal of Infectious Diseases. 1987;155(5) 1011-1019.

[53] Zwick LS, Walsh TF, Barbiers R, Collins MT, Kinsel MJ, Murnane RD. Paratuberculosis in a Mandrill (Papio sphinx). Journal of Veterinary Diagnostic Investigation. 2002;14(4) 326-328.

[54] Beard PM, Rhind SM, Buxton D, Daniels MJ, Henderson D, Pirie A, Rudge K, Greig A, Hutchings MR, Stevenson K, Sharp JM. Natural Paratuberculosis Infection in Rabbits in Scotland. Journal of Comparative Pathology. 2001;124(4) 290-299.

[55] Beard RM, Henderson D, Daniels MJ, Pirie A, Buxton D, Greig A, Hutchings MR, McKendrick I, Rhind S, Stevenson K, Sharp JM. Evidence of Paratuberculosis in Fox (Vulpes vulpes) and Stoat (Mustela erminea). Veterinary Record. 1999;145(21) 612-613.

[56] Florou M, Leontides L, Kostoulas P, Billinis C, Sofia M, Kyriazakis I, Lykotrafitis F. Isolation of Mycobacterium avium subspecies paratuberculosis from Non-Ruminant Wildlife Living in the Sheds and on the Pastures of Greek Sheep and Goats. Epidemiology and Infection. 2008;136(5) 644-652.

[57] Nugent G, Whitford EJ, Hunnam JC, Wilson PR, Cross ML, de Lisle GW. Mycobacterium avium subsp. paratuberculosis Infection in Wildlife on Three Deer Farms with a History of Johne's Disease. New Zealand Veterinary Journal. 2011;59(6) 293-298.

[58] Matos A, Figueira L, Martins M, Matos M, Alvares S, Pinto M, Coelho A. Disseminated Mycobacterium avium subsp. paratuberculosis Infection in Two Wild Eurasian Otters (Lutra lutra L.) from Portugal. Journal of Zoo and Wildlife Medicine (in press). 2012.

[59] Matos A, Figueira L, Martins M, Matos M, Andrade S, Alvares S, Mendes A, Sousa N, Coelho A, Pinto M, editors. Granulomatous Lesions and Mycobacterium avium subsp. paratuberculosis in Portuguese Wild Boars (Sus scrofa).. 30th Meeting of the European Society of Veterinary Pathology; 2012 September 5th to 8th Léon,Spain.

[60] Trcka I, Lamka J, Kopecna M, Beran V, Parmova I, Pavlik I. Mycobacteria in Wild Boar (Sus scrofa) in the Czech Republic. VETERINARSKI ARHIV. 2006;76(Supplement) S27-S32. 
[61] Garrido JM, Vicente J, Carrasco-García R, Galindo RC, Minguijón E, Ballesteros C, Aranaz A, Romero B, Sevilla I, Juste R, de la Fuente J, Gortazar C. Experimental Infection of Eurasian Wild Boar with Mycobacterium avium subsp. avium. Veterinary Microbiology. 2010;144(1-2) 240-245.

[62] Lara GHB, Ribeiro MrG, Leite CQF, Paes AC, Guazzelli A, Silva AVd, Santos ACB, Listoni FJP. Occurrence of Mycobacterium spp. and other Pathogens in Lymph nodes of Slaughtered Swine and Wild Boars (Sus scrofa). Research in Veterinary Science. 2011;90(2) 185-188.

[63] Cvetnić Ž, Špičić S, Tončić J, Račić I, Duvnjak S, Zdelar-Tuk M. Mycobacterium avium subsp. hominissuis in Wild Boar (Sus scrofa) in the Republic of Croatia. Veterinarinarski Arhiv. 2011;81(1) 67-76.

[64] Sah R, Singh S, Arya S. Tuberculosis in some captive zoo birds: case records. Indian Journal of Veterinary Pathology. 1985;9(1) 84-87.

[65] Dvorska L, Matlova L, Ayele WY, Fischer OA, Amemori T, Weston RT, Alvarez J, Beran V, Moravkova M, Pavlik I. Avian Tuberculosis in Naturally Infected Captive Water Birds of the Ardeideae and Threskiornithidae Families Studied by Serotyping, IS901 RFLP Typing, and Virulence for Poultry. Veterinary Microbiology. 2007;119(2-4) 366-374.

[66] Heatley JJ, Mitchell MM, Roy A, Cho DY, Williams DL, Tully TN. Disseminated Mycobacteriosis in a Bald Eagle (Haliaeetus leucocephalus). Journal of Avian Medicine and Surgery. 2007;21(3) 201-209.

[67] Dhama K, Mahendran M, Tomar S. Pathogens Transmitted by Migratory Birds: Threat Perceptions to Poultry Health and Production International Journal of Poultry Science. 2008 7(6) 516-525.

[68] Tell L, Woods L, Cromie R. Mycobacteriosis in Birds. Review Science and Technology Office Internationale des Epizooties. 2001;20(1) 180-203.

[69] Fulton RM, Thoen CO. Tuberculosis In: Saif YM (ed.) Diseases of Poultry. Iowa: Iowa State University Press; 2003. p. 836-844.

[70] Pocknell AM, Miller BJ, Neufeld JL, Grahn BH. Conjunctival Mycobacteriosis in Two Emus (Dromaius novaehollandiae). Veterinary Pathology. 1996;33(3) 346-348.

[71] Lairmore M, Spraker T, Jones R. Two Cases of Tuberculosis in Raptors in Colorado. Journal of Wildlife Diseases. 1985;2154-57.

[72] Millán J, Negre N, Castellanos E, Juan Ld, Mateos A, Parpal L, Aranaz A. Avian mycobacteriosis in free-living raptors in Majorca Island, Spain. 2010;39(1) 1-6.

[73] Miranda C, Matos M, Pires I, Correia-Neves M, Ribeiro P, Ãlvares S, Vieira-Pinto M, Coelho AC. Diagnosis of Mycobacterium avium Complex in Granulomatous Lymphadenitis in Slaughtered Domestic Pigs. Journal of Comparative Pathology. 2012; 
doi: 10.1016/j.jcpa.2012.05.005. http://www.sciencedirect.com/science/article/pii/ S0021997512000849.

[74] OIE. Avian tuberculosis 2010. Available from: http://www.oie.int/en/internationalstandard-setting/terrestrial-> manual/access-online.

[75] Aranaz A, Liébana E, Mateos A, Dominguez L. Laboratory Diagnosis of Avian Mycobacteriosis. Seminars in Avian and Exotic Pet Medicine. 1997;6(1) 9-17.

[76] Altman RB, Clubb SL, Dorrestein GM, Quesenberry K. Avian Medicine and Surgery1997.

[77] Fowler M. Zoo and Wild Animal Medicine Current Therapy 3. Philadelphia: W.B Saunders Company; 1993.

[78] Tell LA, Ferrell ST, Gibbons PM. Avian Mycobacteriosis in Free-Living Raptors in California: 6 Cases (1997-2001). Journal of Avian Medicine and Surgery. 2004;18(1) 30-40.

[79] Chebez J, Aguilar R. Order Falconiformes (Hawks, Eagles, Falcons, Vultures): Infectious Diseases: Avian Mycobacteriosis. In: Fowler ME (ed.) Biology, Medicine, and Surgery of South American Wild Animals. Iowa: Iowa State University Press; 2001. p. 115-124.

[80] Soler D, Brieva C, Ribón W. Mycobacteriosis in Wild Birds : the Potential risk of Disseminating a Little-known Infectious Disease. Revista de Salud Pública. 2009;11(1) 134-144.

[81] Pavlik I, Matlova L, Bartl J, Svastova P, Dvorska L, Whitlock R. Parallel Faecal and Organ Mycobacterium avium subsp. paratuberculosis Culture of Different Productivity Types of Cattle. Veterinary Microbiology. 2000;77(3-4) 309-324.

[82] Tell LA, Foley J, Needham ML, Walker RL. Diagnosis of Avian Mycobacteriosis: Comparison of Culture, Acid-Fast Stains, and Polymerase Chain Reaction for the Identification of Mycobacterium avium in Experimentally Inoculated Japanese Quail (Coturnix coturnix japonica). Avian Diseases. 2003;47(2) 444-452.

[83] Tell LA, Leutenegger CM, Scott Larsen R, Agnew DW, Keener L, Needham ML, Rideout BA. Real-Time Polymerase Chain Reaction Testing for the Detection of Mycobacterium genavense and Mycobacterium avium Complex Species in Avian Samples. Avian Diseases. 2003;47(4) 1406-1415.

[84] Timms VJ, Gehringer MM, Mitchell HM, Daskalopoulos G, Neilan BA. How Accurately can we Detect Mycobacterium avium subsp. paratuberculosis Infection? Journal of Microbiological Methods. 2011;85(1) 1-8.

[85] Whipple DL, Callihan DR, Jarnagin JL. Cultivation of Mycobacterium Paratuberculosis from Bovine Fecal Specimens and a Suggested Standardized Procedure. Journal of Veterinary Diagnostic Investigation. 1991;3(4) 368-373. 
[86] Reddacliff LA, Marsh IB, Fell SA, Austin SL, Whittington RJ. Isolation of Mycobacterium avium subspecies paratuberculosis from Muscle and Peripheral Lymph nodes Using Acid-pepsin Digest Prior to BACTEC Culture. Veterinary Microbiology. 2010;145(1-2) 122-128.

[87] Whitlock RH, Wells SJ, Sweeney RW, Van Tiem J. ELISA and Fecal Culture for Paratuberculosis (Johne's disease): Sensitivity and Specificity of Each Method. Veterinary Microbiology. 2000;77(3-4) 387-398.

[88] Katoch VM. Infections Due to Non-Tuberculous Mycobacteria (NTM). Indian Journal of Medical Research. 2004;120(1) 290-304.

[89] Realini L, De Ridder K, Palomino J-C, Hirschel B, Portaels F. Microaerophilic Conditions Promote Growth of Mycobacterium genavense. Journal of Clinical Microbiology. 1998;36(9) 2565-2570.

[90] Realini L, Van Der Stuyft P, De Ridder K, Hirschel B, Portaels F. Inhibitory Effects of Polyoxyethylene Stearate, PANTA, and Neutral $\mathrm{pH}$ on Growth of Mycobacterium genavense in BACTEC Primary Cultures. Journal of Clinical Microbiology. 1997;35(11) 2791-2794.

[91] Realini L, De Ridder K, Hirschel B, Portaels Fo. Blood and Charcoal Added to Acidified Agar Media Promote the Growth of Mycobacterium genavense. Diagnostic Microbiology and Infectious Disease. 1999;34(1) 45-50.

[92] Kulski JK, Khinsoe C, Pryce T, Christiansen K. Use of a Multiplex PCR to Detect and Identify Mycobacterium avium and M. intracellulare in Blood Culture Fluids of AIDS Patients. Journal of Clinical Microbiology. 1995;33(3) 668-674.

[93] Katoch V, Sharma V. Advances in the Diagnosis of Mycobacterial Diseases. Indian Journal of Medical Microbiology. 1997;15(2) 49-56.

[94] Coelho AC, Pinto ML, Silva S, Coelho AM, Rodrigues J, Juste RA. Seroprevalence of Ovine Paratuberculosis Infection in the Northeast of Portugal. Small Ruminant Research. 2007;71(1-3) 298-303.

[95] Fernández JG, Fernández-de-Mera I, Reyes LE, Ferreras MC, Pérez V, Gortazar C, Fernández M, García-Marín JF. Comparison of Three Immunological Diagnostic Tests for the Detection of Avian Tuberculosis in Naturally Infected Red Deer (Cervus elaphus). Journal of Veterinary Diagnostic Investigation. 2009;21(1) 102-107.

[96] Rozanska M. Preparation of Antigen for Whole Blood Rapid Agglutination Test and its Specificity for Diagnosis of Avian Tuberculosis. Bulletin of Veterinary Institute Pulawy. 1965;9(1) 20-25.

[97] Griffin A, Newton AL, Aronson LR, Brown DC, Hess RS. Disseminated Mycobacterium avium Complex Infection Following Renal Transplantation in a Cat. Journal of the American Veterinary Medical Association. 2003;222(8) 1097-1101. 
[98] Monaghan ML, Doherty ML, Collins JD, Kazda JF, Quinn PJ. The Tuberculin Test. Veterinary Microbiology. 1994;40(1-2) 111-124.

[99] Palmer MV, Waters WR, Whipple DL, Slaughter RE, Jones SL. Evaluation of an in Vitro Blood-Based Assay to Detect Production of Interferon- $\Upsilon$ by Mycobacterium bovis - Infected White-Tailed Deer (Odocoileus Virginianus) Journal of Veterinary Diagnostic Investigation. 2004;16(1) 17-21.

[100] Waters WR, Palmer MV, Thacker TC, Orloski K, Nol P, Harrington NP, Olsen SC, Nonnecke BJ. Blood Culture and Stimulation Conditions for the Diagnosis of Tuberculosis in Cervids by the Cervigam Assay. Veterinary Record. 2008;162(7) 203-208.

[101] Hosek J, Svastova P, Moravkova M, Pavlik I, Bartos M. Methods of Mycobacterial DNA Isolation from Different Biological Material: A Review. Veterinarni Medicina. 2006;51(5) 180-192.

[102] Hurley SS, Splitter GA, Welch RA. Rapid Lysis Technique for Mycobacterial Species. Journal of Clinical Microbiology. 1987;25(11) 2227-2229.

[103] Odumeru J, Gao A, Chen S, Raymond M, Mutharia L. Use of the Bead Beater for Preparation of Mycobacterium paratuberculosis Template DNA in Milk. The Canadian Journal of Veterinary Research. 2001;65(4) 201-205.

[104] Lanigan MD, Vaughan JA, Shiell BJ, Beddome GJ, Michalski WP. Mycobacterial Proteome Extraction: Comparison of Disruption Methods. PROTEOMICS. 2004;4(4) 1094-1100.

[105] Logar K, Kopinc R, Bandelj P, Staric J, Lapanje A, Ocepek M. Evaluation of Combined High-Efficiency DNA Extraction and Real-Time PCR for Detection of Mycobacterium avium subsp. paratuberculosis in Subclinically Infected Dairy Cattle: Comparison with Faecal Culture, Milk Real-Time PCR and Milk ELISA. BMC Veterinary Research. 2012; 8(1):49. http://www.biomedcentral.com/1746-6148/8/49.

[106] Zecconi A, A M, Piccinini R, Robbi C, editors. A Comparison of Six Different Protocols to Extract M. paratuberculosis DNA from Bovine Faeces. 7th International Colloquium on Paratuberculosis; 2003; Bilbao-Spain.

[107] Chui LW, King R, Lu P, Manninen K, Sim J. Evaluation of Four DNA Extraction Methods for the Detection of Mycobacterium avium subsp. paratuberculosis by Polymerase Chain Reaction. Diagnostic Microbiology and Infectious Disease. 2004;48(1) 39-45.

[108] Moravkova M, Hlozek P, Beran V, Pavlik I, Preziuso S, Cuteri V, Bartos M. Strategy for the Detection and Differentiation of Mycobacterium avium Species in Isolates and Heavily Infected Tissues. Research in Veterinary Science. 2008;85(2) 257-264.

[109] Slana I, Pribylova R, Kralova A, Pavlik I. Persistence of Mycobacterium avium subsp. paratuberculosis at a Farm-Scale Biogas Plant Supplied with Manure from Paratuberculosis-Affected Dairy Cattle. Applied and Environmental Microbiology. 2011;77(9) 3115-3119. 
[110] Saiki R, Scharf S, Faloona F, Mullis K, Horn G, Erlich H, Arnheim N. Enzymatic Amplification of Beta-globin Genomic Sequences and Restriction Site Analysis for Diagnosis of Sickle Cell Anemia. Science. 1985;230(4732) 1350-1354.

[111] Lo YMD, Chiu RWK, Chan KCA, editors. Clinical Applications of PCR. Second Edition ed. New Jersey: Humana Press; 2006.

[112] Lachnik J, Ackermann B, Bohrssen A, Maass S, Diephaus C, Puncken A, Stermann M, Bange F-C. Rapid-Cycle PCR and Fluorimetry for Detection of Mycobacteria. Journal of Clinical Microbiology. 2002;40(9) 3364-3373.

[113] Devallois A, Picardeau M, Goh KS, Sola C, Vincent V, Rastogi N. Comparative Evaluation of PCR and Commercial DNA Probes for Detection and Identification to Species Level of Mycobacterium avium and Mycobacterium intracellulare. Journal of Clinical Microbiology. 1996;34(11) 2756-2759.

[114] Schweickert B, Goldenberg O, Richter E, Göbel UB, Petrich A, Buchholz P, Moter A. Occurrence and Clinical Relevance of Mycobacterium chimaera sp. nov., Germany. Emerging Infectious Diseases. 2008;14(9) 1443-1446.

[115] Green EP, Tizard MLV, Moss MT, Thompson J, Winterbourne DJ, McFadden JJ, Hermon-Taylor J. Sequence and Characteristics or IS900, an Insertion Element Identified in a Human Crohn's Disease Isolate or Mycobacterium paratuberculosis. Nucleic Acids Research. 1989;17(22) 9063-9073.

[116] Green E, Tizard M, Moss M, Thompson J, Winterbourne D, Mc Fadden J, HermonTaylor J. Sequence and Characteristics of IS900, an Insertion Element Identified in a Human Crohn's Disease Isolate of Mycobacterium paratuberculosis. Nucleic Acids Research. 1989;17(22) 9063 - 9073.

[117] Kunze ZM, Wall S, Appelberg R, Silva MT, Portaels F, McFadden JJ. IS901, A New Member of a Widespread Class of Atypical Insertion Sequences, is Associated with Pathogenicity in Mycobacterium avium. Molecular Microbiology. 1991;5(9) 2265-2272.

[118] Guerrero C, Bernasconi C, Burki D, Bodmer T, Telenti A. A Novel Insertion Element from Mycobacterium avium, IS1245, is a Specific Target for Analysis of Strain Relatedness. Journal of Clinical Microbiology. 1995;33(2) 304-307.

[119] Roiz MP, Palenque E, Guerrero C, Garcia MJ. Use of Restriction Fragment Length Polymorphism as a Genetic Marker for Typing Mycobacterium avium strains. Journal of Clinical Microbiology. 1995;33(5) 1389-1391.

[120] Bartos M, Hlozek P, Svastova P, Dvorska L, Bull T, Matlova L, Parmova I, Kuhn I, Stubbs J, Moravkova M, Kintr J, Beran V, Melicharek I, Ocepek M, Pavlik I. Identification of Members of Mycobacterium avium species by Accu-Probes, Serotyping, and Single IS900, IS901, IS1245 and IS901-Flanking Region PCR with Internal Standards. Journal of Microbiological Methods. 2006;64(3) 333-345. 
[121] Collins D, Gabric D, de Lisle G. Identification of a Repetitive DNA Sequence Specific to Mycobacterium paratuberculosis. FEMS Microbiology Letters. 1989;51(1) 175 - 178.

[122] Li L, Bannantine JP, Zhang Q, Amonsin A, May BJ, Alt D, Banerji N, Kanjilal S, Kapur V. The Complete Genome Sequence of Mycobacterium avium subspecies paratuberculosis. Proceedings of the National Academy of Sciences of the United States of America. 2005;102(35) 12344-12349.

[123] Cousins DV, Whittington R, Marsh I, Masters A, Evans RJ, Kluver P. Mycobacteria Distinct from Mycobacterium avium subsp. paratuberculosis Isolated from the Faeces of Ruminants Possess IS 900 -like Sequences Detectable by IS 900 Polymerase Chain Reaction: Implications for Diagnosis. Molecular and Cellular Probes. 1999;13(6) 431-442.

[124] Englund S, Bölske G, Johansson K-E. An IS900-like Sequence Found in a Mycobacterium sp. Other Than Mycobacterium avium subsp. paratuberculosis. FEMS Microbiology Letters. 2002;209(2) 267-271.

[125] Vansnick E, de Rijk P, Vercammen F, Geysen D, Rigouts L, Portaels F. Newly Developed Primers for the Detection of Mycobacterium avium subspecies paratuberculosis. Veterinary Microbiology. 2004;100(3-4) 197-204.

[126] Stabel JR, Wells SJ, Wagner BA. Relationships Between Fecal Culture, ELISA, and Bulk Tank Milk Test Results for Johne's Disease in US Dairy Herds. Journal of Dairy Science. 2002;85(3) 525-531.

[127] Slana I, Kralik P, Kralova A, Pavlik I. On-farm Spread of Mycobacterium avium subsp. paratuberculosis in Raw Milk Studied by IS900 and F57 Competitive Real Time Quantitative PCR and Culture Examination. International Journal of Food Microbiology. 2008;128(2) 250 - 257.

[128] Sanna E, Woodall CJ, Watt NJ, Clarke CJ, Pittau M, Leoni A, Nieddu AM. In situPCR for the Detection of Mycobacterium paratuberculosis DNA in Paraffin-embedded Tissues. European Journal of Histochemistry. 2000;44(2) 179-184.

[129] Corti S, Stephan R. Detection of Mycobacterium avium subspecies paratuberculosis Specific IS900 Insertion Sequences in Bulk-Tank Milk Samples Obtained from Different Regions throughout Switzerland. BMC Microbiology. 2002;2(1) 15.

[130] Doosti A, Moshkelani S. Application of IS900 Nested-PCR for Detection of Mycobacterium avium subsp. paratuberculosis Directly from Faecal Specimens. Bulgarian Journal of Veterinary Medicine. 2010;13(2) 92-97.

[131] Rajeev S, Zhang Y, Sreevatsan S, Motiwala AS, Byrum B. Evaluation of Multiple Genomic Targets for Identification and Confirmation of Mycobacterium avium subsp. paratuberculosis Isolates Using Real-Time PCR. Veterinary Microbiology. 2005;105(3-4) 215-221.

[132] Pribylova R, Slana I, Lamka J, Babak V, Hruska K, Pavlik I. Mycobacterium avium subsp. paratuberculosis in a Mouflon Herd without Clinical Symptoms Monitored 
Using IS900 Real-Time PCR: A Case Report. Veterinarni Medicina. 2010;55(12) 625-630.

[133] Salgado M, Herthnek D, Bölske G, Leiva S, Kruze J. First Isolation of Mycobacterium avium subsp. paratuberculosis from Wild Guanacos (Lama Guanicoe) on Tierra del Fuego Island. Journal of Wildlife Diseases. 2009;45(2) 295-301.

[134] Strommenger B, Stevenson K, Gerlach G-F. Isolation and Diagnostic Potential of ISMav2, a Novel Insertion Sequence-like Element from Mycobacterium avium subspecies paratuberculosis. FEMS Microbiology Letters. 2001;196(1) 31-37.

[135] Poupart P, Coene M, Van Heuverswyn H, Cocito C. Preparation of a Specific RNA Probe for Detection of Mycobacterium paratuberculosis and Diagnosis of Johne's Disease. Journal of Clinical Microbiology. 1993;31(6) 1601-1605.

[136] Stabel JR, Bannantine JP. Development of a Nested PCR Method Targeting a Unique Multicopy Element, ISMap02, for Detection of Mycobacterium avium subsp. paratuberculosis in Fecal Samples. Journal of Clinical Microbiology. 2005;43(9) 4744-4750.

[137] Bannantine JP, Baechler E, Zhang Q, Li L, Kapur V. Genome Scale Comparison of Mycobacterium avium subsp. paratuberculosis with Mycobacterium avium subsp. avium Reveals Potential Diagnostic Sequences. Journal of Clinical Microbiology. 2002;40(4) 1303-1310.

[138] Möbius P, Hotzel H, Raßbach A, Köhler H. Comparison of 13 Single-Round and Nested PCR Assays Targeting IS900, ISMav2, f57 and locus 255 for Detection of Mycobacterium avium subsp. paratuberculosis. Veterinary Microbiology. 2008;126(4) 324-333.

[139] Englund S, Ballagi-Pordány A, Bölske G, Johansson K-E. Single PCR and Nested PCR with a Mimic Molecule for Detection of Mycobacterium avium subsp. paratuberculosis. Diagnostic Microbiology and Infectious Disease. 1999;33(3) 163-171.

[140] Doran TJ, Davies JK, Radford AJ, Hodgson ALM. Putative Functional Domain within ORF2 on the Mycobacterium Insertion Sequences IS900 and IS902. Immunology and Cell Biology. 1994;72(5) 427-434.

[141] Devallois A, Rastogi N. Computer-Assisted Analysis of Mycobacterium avium Fingerprints Using Insertion Elements IS1245 and IS1311 in a Caribbean Setting. Research in Microbiology. 1997;148(8) 703-713.

[142] Collins DM, Cavaignac S, de Lisle GW. Use of four DNA Insertion Sequences to Characterize Strains of the Mycobacterium avium complex isolated from animals. Molecular and Cellular Probes. 1997;11(5) 373-380.

[143] van Soolingen D, Bauer J, Ritacco V, Leão SC, Pavlik I, Vincent V, Rastogi N, Gori A, Bodmer T, Garzelli C, Garcia MJ. IS1245 Restriction Fragment Length Polymorphism Typing of Mycobacterium avium Isolates: Proposal for Standardization. Journal of Clinical Microbiology. 1998;36(10) 3051-3054. 
[144] Beggs ML, Stevanova R, Eisenach KD. Species Identification of Mycobacterium avium Complex Isolates by a Variety of Molecular Techniques. Journal of Clinical Microbiology. 2000;38(2) 508-512.

[145] Wilton S, Cousins D. Detection and Identification of Multiple Mycobacterial Pathogens by DNA Amplification in a Single Tube. Genome Research. 1992;1(4) 269-273.

[146] Godfroid J, Delcorps C, Irenge LM, Walravens K, Marché S, Gala J-L. Definitive Differentiation between Single and Mixed Mycobacterial Infections in Red Deer (Cervus elaphus) by a Combination of Duplex Amplification of p34 and f57 Sequences and Hpy188I Enzymatic Restriction of Duplex Amplicons. Journal of Clinical Microbiology. 2005;43(9) 4640-4648.

[147] Semret M, Turenne CY, de Haas P, Collins DM, Behr MA. Differentiating Host-Associated Variants of Mycobacterium avium by PCR for Detection of Large Sequence Polymorphisms. Journal of Clinical Microbiology. 2006;44(3) 881-887.

[148] Dvorská L, Bartoš M, Martin G, Erler W, Pavlík I. Strategies for Differentiation, Identification and Typing of Medically Important Species of Mycobacteria by Molecular Methods. Veterinarni Medicina. 2001;46(11-12) 309-328.

[149] Nagai R, Takewaki S, Wada A, Okuzumi K, Tobita A, Ohkubo A. Development of Rapid Detection Method for Mycobacteria using PCR. Journal of Medical Technology (In Japanese). 1990;38(1) 1247-1252.

[150] Cirillo JD, Falkow S, Tompkins LS, Bermudez LE. Interaction of Mycobacterium avium with Environmental Amoebae Enhances Virulence. Infection and Immunity. 1997;65(9) 3759-3767.

[151] Arasteh KN, Cordes C, Ewers M, Simon V, Dietz E, Futh UM, Brockmeyer NH, L'Age MP. HIV-Related Nontuberculous Mycobacterial Infection: Incidence, Survival Analysis and Associated Risk Factors. European journal of medical research. 2000;5(10) 424-430.

[152] Nightingale SD, Byrd LT, Southern PM, Jockusch JD, Cal SX, Wynne BA. Incidence of Mycobacterium avium-intracellulare Complex Bacteremia in Human Immunodeficiency Virus-Positive Patients. Journal of Infectious Diseases. 1992;165(6) 1082-1085.

[153] Salte T, Pathak S, Wentzel-Larsen T, Åsjö B. Increased Intracellular Growth of Mycobacterium avium in HIV-1 Exposed Monocyte-Derived Dendritic Cells. Microbes and Infection. 2011;13(3) 276-283.

[154] Wallace JM, Hannah JB. Mycobacterium avium Complex Infection in Patients with the Acquired Immunodeficiency Syndrome. A Clinicopathologic Study. CHEST Journal. 1988;93(5) 926-932.

[155] Crowe SM, Carlin JB, Stewart KI, Lucas CR, Hoy JF. Predictive Value of CD4 Lymphocyte Numbers for the Development of Opportunistic Infections and Malignancies in HIV-Infected Persons. Journal of acquired immune deficiency syndromes. 1991;4(8) 770-776. 
[156] Bodle E, Cunningham J, Della-Latta P, Schluger N, Saiman L. Epidemiology of Nontuberculous Mycobacteria in Patients without HIV Infection. Emerging Infectious Diseases. 2008;14(3) 390-396.

[157] Henry MT, Inamdar L, O'Riordain D, Schweiger M, Watson JP. Nontuberculous Mycobacteria in non-HIV Patients: Epidemiology, Treatment and Response. European Respiratory Journal. 2004;23(5) 741-746.

[158] Maugein J, Dailloux M, Carbonnelle B, Vincent V, Grosset J. Sentinel-site Surveillance of Mycobacterium avium Complex Pulmonary Disease. European Respiratory Journal. 2005;26(6) 1092-1096.

[159] Falkinham JI. Nontuberculous mycobacteria from household plumbing of patients with nontuberculous mycobacteria disease. Emerging Infectious Diseases. 2011;17(3) 419-424.

[160] Koh W-J, Lee JH, Kwon YS, Lee KS, Suh GY, Chung MP, Kim H, Kwon OJ. Prevalence of Gastroesophageal Reflux Disease in Patients with Nontuberculous Mycobacterial Lung Disease*. CHEST Journal. 2007;131(6) 1825-1830.

[161] Hernández-Garduño E, Elwood K. Nontuberculous Mycobacteria in Tap Water. Emerging Infectious Diseases. 2012;18(2) 353.

[162] Thegerström J, Romanus V, Friman V, Brudin L, Haemig P, Olsen B. Mycobacterium avium lymphadenopathy among children. Emerging Infectious Diseases. 2008;14(4) 661-663.

[163] Jindal N, Devi B, Aggarwal A. Mycobacterial Cervical Lymphadenitis in Childhood. Indian Journal of Medical Sciences. 2003;57(1) 12-15.

[164] Primm TP, Lucero CA, Falkinham JO. Health Impacts of Environmental Mycobacteria. Clinical Microbiology Reviews. 2004;17(1) 98-106.

[165] Bodmer T, Miltner E, Bermudez LE. Mycobacterium avium Resists Exposure to the Acidic Conditions of the Stomach. FEMS Microbiology Letters. 2000;182(1) 45-49.

[166] Hoop RK. Public Health Implications of Epet Mycobacteriosis. Seminars in Avian and Exotic Pet Medicine. 1997;6(1) 3-8.

[167] Suzuki AE, Inamine JM. Genetic Aspects of Drug Resistance in Mycobacterium avium. Research in Microbiology. 1994;145(3) 210-213.

[168] Hellinger WC, Smilack JD, Greider JL, Alvarez S, Trigg SD, Brewer NS, Edson RS. Localized Soft-Tissue Infections with Mycobacterium avium / Mycobacterium intracellulare Complex in Immunocompetent Patients: Granulomatous Tenosynovitis of the Hand or Wrist. Clinical Infectious Diseases. 1995;21(1) 65-69.

[169] Horsburgh CR, Selik RM. The Epidemiology of Disseminated Nontuberculous Mycobacterial Infection in the Acquired Immunodeficiency Syndrome (AIDS). American Journal of Respiratory and Critical Care Medicine. 1989;139(1) 4-7. 
[170] Modilevsky T, Sattler FR, Barnes PF. Mycobacterial Disease in Patients with Human Immunodeficiency Virus Infection. Archives of Internal Medicine. 1989;149(10) 2201-2205.

[171] Hermon-Taylor J, Bull TJ, Sheridan JM, Cheng J, Stellakis ML, Sumar N. Causation of Crohn's Disease by Mycobacterium avium subspecies paratuberculosis. Canadian Journal of Gastroenterology. 2000;14(6) 521-539.

[172] Bernstein CN, Blanchard JF, Rawsthorne P, Collins MT. Population-Based Case Control Study of Seroprevalence of Mycobacterium paratuberculosis in Patients with Crohn's Disease and Ulcerative Colitis. Journal of Clinical Microbiology. 2004;42(3) 1129-1135.

[173] Grant IR. Zoonotic Potential of Mycobacterium avium ssp. paratuberculosis: The Current Position. Journal of Applied Microbiology. 2005;98(6) 1282-1293.

[174] Wall S, Kunze ZM, Saboor S, Soufleri I, Seechurn P, Chiodini R, McFadden JJ. Identification of Spheroplast-like Agents Isolated from Tissues of patients with Crohn's Disease and Control Tissues by Polymerase Chain Reaction. Journal of Clinical Microbiology. 1993;31(5) 1241-1245.

[175] Hines II ME, Styer EL. Preliminary Characterization of Chemically Generated Mycobacterium avium subsp. paratuberculosis Cell Wall Deficient Forms (Spheroplasts). Veterinary Microbiology. 2003;95(4) 247-258.

[176] Sechi LA, Mura M, Tanda E, Lissia A, Fadda G, Zanetti S. Mycobacterium avium sub. paratuberculosis in Tissue samples of Crohn's Disease Patients. The new microbiologica. 2004;27(1) 75-77.

[177] Bull TJ, McMinn EJ, Sidi-Boumedine K, Skull A, Durkin D, Neild P, Rhodes G, Pickup R, Hermon-Taylor J. Detection and Verification of Mycobacterium avium subsp. paratuberculosis in Fresh Ileocolonic Mucosal Biopsy Specimens from Individuals with and without Crohn's Disease. Journal of Clinical Microbiology. 2003;41(7) 2915-2923.

[178] Naser SA, Ghobrial G, Romero C, Valentine JF. Culture of Mycobacterium avium subspecies paratuberculosis from the Blood of Patients with Crohn's Disease. The Lancet. 2004;364(9439) 1039-1044.

[179] Bitti MLM, Masala S, Capasso F, Rapini N, Piccinini S, Angelini F, Pierantozzi A, Lidano R, Pietrosanti S, Paccagnini D, Sechi LA. Mycobacterium avium subsp. paratuberculosis in an Italian Cohort of Type 1 Diabetes Pediatric Patients. Clinical and Developmental Immunology. 2012;20121-5.

[180] Naser SA, Collins MT, Crawford JT, Valentine JF. Culture of Mycobacterium avium subspecies paratuberculosis (MAP) from the Blood of Patients with Crohn's disease: A Follow-Up Blind Multi Center Investigation. The Open Inflammation Journal. 2009;2(1) 22-23. 
[181] Parrish NM, Radcliff RP, Brey BJ, Anderson JL, Clark DL, Koziczkowski JJ, Ko CG, Goldberg ND, Brinker DA, Carlson RA, Dick JD, Ellingson JLE. Absence of Mycobacterium avium subsp. paratuberculosis in Crohn's Patients. Inflammatory Bowel Diseases. 2009;15(4) 558-565.

[182] Dow CT. Paratuberculosis and Type I Diabetes Is this the Trigger? Medical Hypotheses. 2006;67(4) 782-785.

[183] D'Amore M, Lisi S, Sisto M, Cucci L, Dow CT. Molecular Identification of Mycobacterium avium subspecies paratuberculosis in an Italian Patient with Hashimoto's Thyroiditis and Melkersson-Rosenthal Syndrome. Journal of Medical Microbiology. 2010;59(1) 137-139.

[184] Dow CT. Mycobacterium paratuberculosis and autism: Is this a trigger? Medical Hypotheses. 2011;77(6) 977-981.

[185] Dow CT, Ellingson JLE. Detection of Mycobacterium avium ss. paratuberculosis in Blau Syndrome Tissues. Autoimmune Diseases. 2010;2010.

[186] el-Zaatari FA, Naser SA, Markesich DC, Kalter DC, Engstand L, Graham DY. Identification of Mycobacterium avium complex in sarcoidosis. Journal of Clinical Microbiology. 1996;34(9) 2240-2245.

[187] Oliveira-Filho JP, Monteiro LN, Delfiol DJZ, Sequeira JL, Amorim RM, Fabris VE, Del Piero F, Borges AS. Mycobacterium DNA Detection in Liver and Skin of a Horse with Generalized Sarcoidosis. Journal of Veterinary Diagnostic Investigation. 2012;24(3) 596-600.

[188] Rook G, McCulloch J. HLA-DR4, Mycobacteria, Heat-Shock Proteins, and Rheumatoid Arthritis. Arthritis \& Rheumatism. 1992;35(12) 1409-1412.

[189] Mangiapan G, Hance A. Mycobacteria and Sarcoidosis: An Overview and Summary of Recent Molecular Biological Data. Sarcoidosis. 1995;12(1) 20-37.

[190] Rosu V, Ahmed N, Paccagnini D, Pacifico A, Zanetti S, Sechi L. Mycobacterium avium subspecies paratuberculosis Is not Associated with Type-2 Diabetes Mellitus. Annals of Clinical Microbiology and Antimicrobials. 2008;7(1) 9.

[191] Sechi LA, Paccagnini D, Salza S, Pacifico A, Ahmed N, Zanetti S. Mycobacterium avium Subspecies paratuberculosis Bacteremia in Type 1 Diabetes Mellitus: An Infectious Trigger? Clinical Infectious Diseases. 2008;46(1) 148-149.

[192] Sechi LA, Rosu V, Pacifico A, Fadda G, Ahmed N, Zanetti S. Humoral Immune Responses of Type 1 Diabetes Patients to Mycobacterium avium subsp. paratuberculosis Lend Support to the Infectious Trigger Hypothesis. Clinical and Vaccine Immunology. 2008;15(2) 320-326.

[193] Paccagnini D, Sieswerda L, Rosu V, Masala S, Pacifico A, Gazouli M, Ikonomopoulos J, Ahmed N, Zanetti S, Sechi LA. Linking Chronic Infection and Autoimmune Diseases: Mycobacterium avium Subspecies paratuberculosis,SLC11A1 Polymorphisms 
and Type-1 Diabetes Mellitus. PLoS ONE. 2009; 4(9):e7109. http://dx.doi.org/ 10.1371\%2Fjournal.pone.0007109.

[194] Rosu V, Ahmed N, Paccagnini D, Gerlach G, Fadda G, Hasnain SE, Zanetti S, Sechi LA. Specific Immunoassays Confirm Association of Mycobacterium avium Subsp. paratuberculosis with Type-1 but Not Type-2 Diabetes Mellitus. PLoS ONE. 2009; 4(2):e4386. http://dx.doi.org/10.1371\%2Fjournal.pone.0004386.

[195] Cossu A, Rosu V, Paccagnini D, Cossu D, Pacifico A, Sechi LA. MAP3738c and MptD are specific tags of Mycobacterium avium subsp. paratuberculosis infection in type I diabetes mellitus. Clinical Immunology. 2011;141(1) 49-57. 